\title{
PERAN IKAN DALAM POLA KONSUMSI PANGAN HEWANI RUMAH TANGGA INDONESIA: ANALISIS DATA SUSENAS 1996-2002
}

\author{
Siti Hajar Suryawati", Subhechanis Saptanto", Mewa Ariani“") dan Sonny Koeshendrajana")
}

\begin{abstract}
ABSTRAK
Penelitian ini bertujuan untuk mengkaji peran ikan dalam perkembangan pola konsumsi pangan hewani rumah tangga di Indonesia. Data yang dipublikasikan oleh BPS (Biro Pusat Statistik) untuk tahun 1996 sampai dengan 2002 seperti nilai konsumsi dan nilai pengeluaran untuk daging, telur, susu dan ikan digunakan dalam kajian ini. Hasil penelitian menunjukkan pola konsumsi pangan hewani di Indonesia pada tahun 1996 adalah Daging-lkan-Telur-Susu. Terjadi perubahan pola konsumsi pangan hewani pada tahun 1999 dan 2002 yaitu Ikan-DagingTelur-Susu. Hal ini menunjukkan bahwa ikan sangat berperan dalam menyumbang protein hewani dalam mutu gizi makanan rumah tangga Indonesia.
\end{abstract}

ABSTRACT: Role of fish in the protein meat consumption pattern of households in Indonesia: An analysis of National Socio Economic Survey (NSES data) 1996-2002. By: Siti Hajar Suryawati, Subhechanis Saptanto, Mewa Ariani, and Sonny Koeshendrajana

This research objective was to analyse the fish's role in consumption pattern growth of meat as food for households in Indonesia. Data publicized by BPS (Central Bureau of Statistics) for the year of 1996 up to 2002 such as data of consumption and expenditure value for the meat, egg, fish and milk used in this study. Result of research show the consumption pattern of meat as food for household in Indonesia in the year 1996 was Meat-Fish-Egg-Milk. A change of consumption pattern of stock meat as food in the year 1999 and 2002 was Fish-Meat-Egg-Milk. This matter indicated that fish played an important role in contributing protein from meat in food quality of Indonesian households.

KEYWORD: fish, consumption pattern, meat consumption pattem

\section{PENDAHULUAN}

Orientasi pemenuhan kebutuhan pangan saat ini bukan lagi hanya pada pemenuhan kuantitas saja, tetapi juga segi kualitas pangan yang diproduksi, diperdagangkan dan dikonsumsi. Tujuan akhirnya adalah meningkatkan kualitas sumberdaya manusia melalui perbaikan mutu gizi makanannya (Almatsier, 2002). Mutu gizi makanan sangat ditentukan oleh kecukupan dan mutu zat-zat gizi esensial di dalamnya, diantaranya protein. Berdasarkan sumbernya, protein digolongkan menjadi dua yaitu protein nabati dan protein hewani. Protein hewani mempunyai mutu yang lebih tinggi dibandingkan dengan protein nabati. Pangan hewani tersebut diantaranya adalah daging, telur, susu dan ikan.

Protein ikan kaya akan asam-asam amino esensial yang lebih lengkap susunannya (lebih mendekati pada susunan protein tubuh manusia) sehingga sangat diperlukan dalam tubuh manusia. Bahan pangan yang tergolong sumber protein tinggi, pada umumnya mengandung $16-33 \%$ protein (Lubis 1987). Ikan laut memiliki asam lemak omega-3, vitamin dan mineral yang tinggi. Sebaliknya, ikan air tawar terutama tinggi karbohidrat dan asam lemak omega-6. Kedua jenis ikan tersebut merupakan sumber zat gizi yang bermutu sehingga dapat secara bergantian dikonsumsi agar saling melengkapi kekurangan zat gizi lainnya (Harli, 2004).

Dengan luas laut 5,8 juta $\mathrm{km}^{2}$, Indonesia sesungguhnya memiliki potensi sumberdaya perikanan laut yang cukup besar baik dari segi kuantitas maupun keragamannya. Kekayaan flora dan fauna yang dimiliki terutama dari laut merupakan sumber gizi bagi masyarakatnya. Hal ini penting untuk mencerdaskan bangsa Indonesia bila sumber pangan terutama ikan dan hail laut lainnya dikonsumsi oleh masyarakat secara merata (Wahyuni, 1994).

Selain itu, produksi perikanan dalam periode 2000 2004 mengalami peningkatan rata-rata per tahun sebesar $5.23 \%$, yakni 5.107 juta ton pada tahun 2000 menjadi 6.231 juta ton pada tahun 2004, khususnya penangkapan di laut. Dalam periode yang sama, produksi perikanan tangkap secara keseluruhan meningkat sekitar 4,21\% per tahun, yakni dari 4.112

\footnotetext{
- Peneliti pada Balai Besar Riset Sosial Ekonomi Kelautan dan Perikanan

*) Peneliti pada Pusat Analisis Kebijakan dan Sosial Ekonomi Pertanian,Bogor
} 
juta ton pada tahun 2000 menjadi 4.837 juta ton pada tahun 2004. Pada kategori kegiatan usaha budidaya, pada tahun 2002 saja, lingkungan perairan air tawar memberikan kontribusi sebesar $7,78 \%(429,166$ ton); sedangkan lingkungan perairan payau dan laut memberikan kontribusi sebesar $12,84 \%$ ( 707,987 ton). Teknologi pengelolaan budidaya yang digunakan dapat dikelompokkan kedalam budidaya kolam, karamba jaring apung (KJA), tambak dan budidaya di sawah (Departemen Kelautan dan Perikanan/DKP, 2004).

Berdasarkan Widyakarya Nasional Pangan dan Gizi VIII (WKNPG, 2004), angka kecukupan protein hewani yang dianjurkan adalah $15 \mathrm{~g} / \mathrm{kap} / \mathrm{hr}(9 \mathrm{~g} / \mathrm{kap} /$ $\mathrm{hr}$ dari perikanan dan $6 \mathrm{~g} / \mathrm{kap} / \mathrm{hr}$ dari peternakan). Setelah dikonversi menjadi $\mathrm{kg} / \mathrm{kap} / \mathrm{th}$ maka konsumsi ikan agar memenuhi kecukupan protein yang dianjurkan adalah $24,2 \mathrm{~kg} / \mathrm{kap} / \mathrm{th}$ atau setara dengan $66,3 \mathrm{~g} / \mathrm{kap} / \mathrm{hr}$.

Pada tahun-tahun belakangan ini konsumsi ikan masyarakat Indonesia cenderung meningkat. Perkembangan konsumsi ikan per kapita nasional pada periode tahun 2000-2004 mengalami peningkatan sebesar $1,68 \%$, yakni dari $21,57 \mathrm{~kg} /$ $\mathrm{kap} / \mathrm{thn}$ pada tahun 2000 menjadi $23,18 \mathrm{~kg} / \mathrm{kap} / \mathrm{thn}$ pada tahun 2004 (DKP, 2004). Jika dibandingkan dengan beberapa negara lain yang termasuk ke dalam negara penghasil ikan dunia, maka Indonesia adalah negara dengan konsumsi per kapita paling rendah, bahkan lebih rendah dibandingkan dengan Philipina. Sebagai contoh, misalnya pada tahun 1990 saja, konsumsi per kapita Philipina sudah mencapai $24 \mathrm{~kg} / \mathrm{kap} / \mathrm{tahun}$, sementara, konsumsi per kapita Jepang mencapai $110 \mathrm{~kg} / \mathrm{kap} /$ tahun (Dahuri, 2002).

Upaya peningkatan konsumsi ikan per kapita dipengaruhi oleh berbagai faktor, diantaranya adalah kedudukan ikan itu sendiri dalam dalam pola konsumsi pangan hewani, yaitu susunan pangan hewani yang secara teratur dan terus menerus dikonsumsi oleh masyarakat. Penelitian bertujuan mengkaji peranan ikan dalam pola konsumsi pangan hewani dalam kurun waktu tahun 1996 sampai 2002 berdasarkan wilayah di Indonesia.

\section{METODE}

\section{Ruang Lingkup dan Sumber Data}

Kajian ini didasarkan pada data mentah Survey Sosial Ekonomi Nasional (SUSENAS) yang merupakan survei rumah tangga dengan lingkup nasional dan dilakukan secara sampel untuk tahun 1996, 1999 dan 2002 yang dikumpulkan oleh Badan Pusat Statistik (BPS). Data yang digunakan pada kajian ini adalah data nilai pengeluaran dan data konsumsi untuk pangan hewani (daging, telur, susu dan ikan) yang bersumber dari data sekunder berupa data (SUSENAS).

\section{Metode Pengumpulan dan Analisis Data}

Analisis deskriptif dilakukan berdasarkan tabulasi silang yang dibuat dari hasil pengolahan data SUSENAS tahun 1996, 1999 dan 2002. Periode tahun 1996, 1999 dan 2002 diharapkan dapat memebrikan gambaran kondisi konsumsi ikan di Indonesia pada masa sebelum krisis ekonomi (1996), masa krisis ekonomi (1999) dan masa pemulihan setelah krisis ekonomi (2000).

Selanjutnya data-data yang dimaksudkan dalam kajian ini diolah untuk mengetahui tingkat konsumsi protein pangan hewani (daging, telur, ikan dan susu) dalam satuan $\mathrm{kg} / \mathrm{kap} / \mathrm{tahun}$ menurut wilayah (propinsi, desa-kota), kemudian dianalisis menggunakan metode analisis deskriptif dengan proses tabulasi. Setelah tingkat konsumsi ikan diketahui, selanjutnya adalah penyusunan pola konsumsi pangan hewaninya. Pola konsumsi pangan hewani dapat digunakan sebagai salah satu indikator kesukaan (preferensi) dan daya jangkau (daya jangkau fisik dan daya beli) penduduk terhadap jenis-jenis komoditas pangan hewani yangsangat berperan dalam menyumbang protein hewani di Indonesia.

\section{HASIL DAN BAHASAN}

\section{Perkembangan Pola Konsumsi Pangan Hewani}

Menurut ahli antropologi Margaret Mead dalam Almatsier (2002) disebutkan bahwa pola konsumsi pangan (food pattern) adalah cara seseorang atau sekelompok orang memanfaatkan pangan yang tersedia sebagai reaksi terhadap tekanan ekonomi dan sosio budaya yang dialaminya.

Pola konsumsi pangan individu biasanya berhubungan dengan kebiasaan makanan masyarakat dan ekologi tempat dimana ia berada. Kegiatan konsumsi pangan ditentukan oleh 3 (tiga) variabel, yaitu fisik, budaya dan ekologi. Ada beberapa fungsi sosial dari kegiatan konsumsi pangan (makan), yaitu (1) fungsi pencernaan; (2) sebagai sarana identitas budaya; (3) fungsi religius dan magis; (4) sarana komunikasi; (5) mencerminkan status dan kesejahteraan ekonomi; dan (6) sarana untuk memperoleh kekuatan tubuh.

Oleh karena itu, pola konsumsi pangan dapat diartikan sebagai susunan makanan yang biasa atau secara teratur dan terus menerus dikonsumsi oleh masyarakat. Berdasarkan kelompok pangannya, 


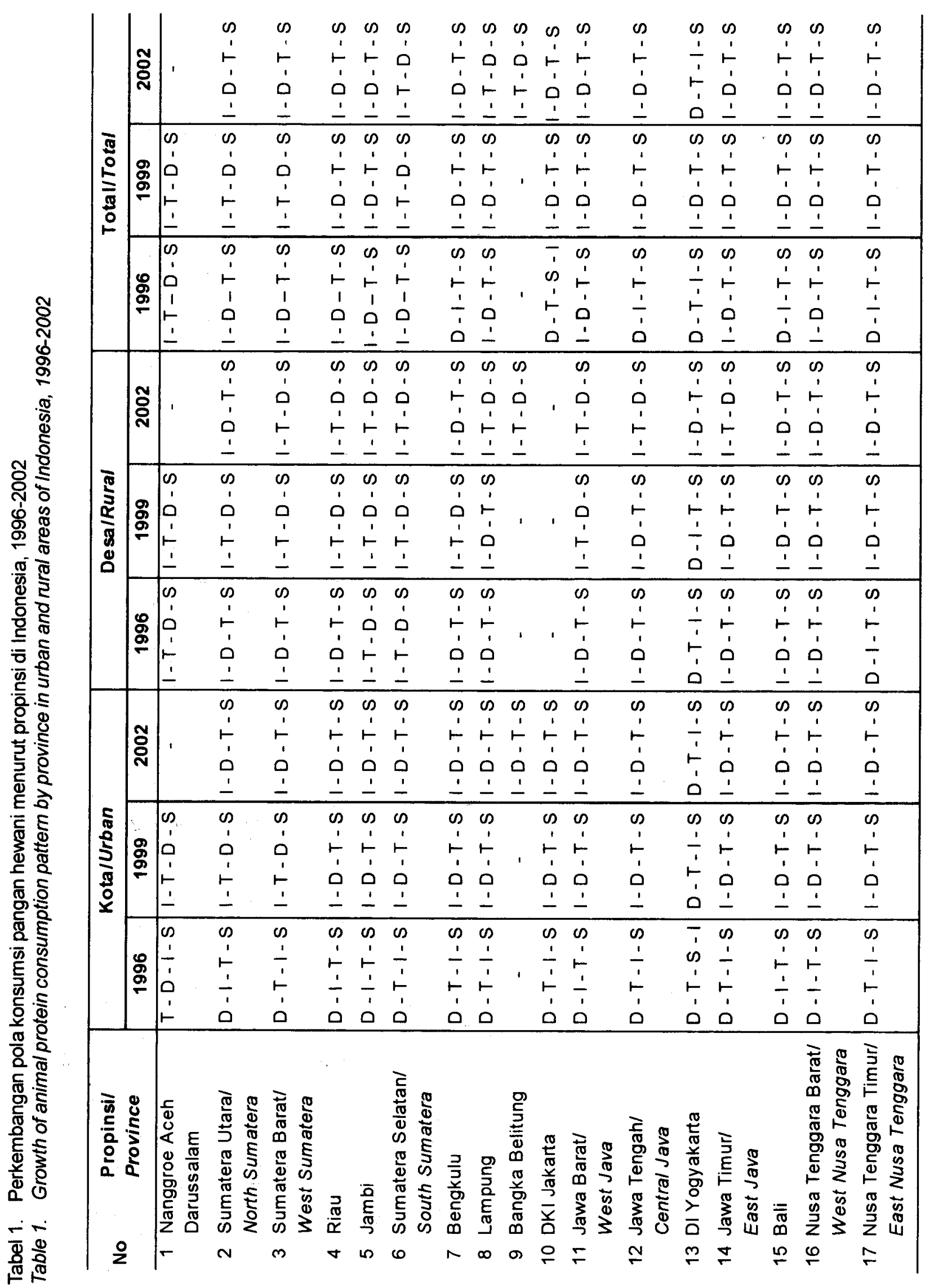




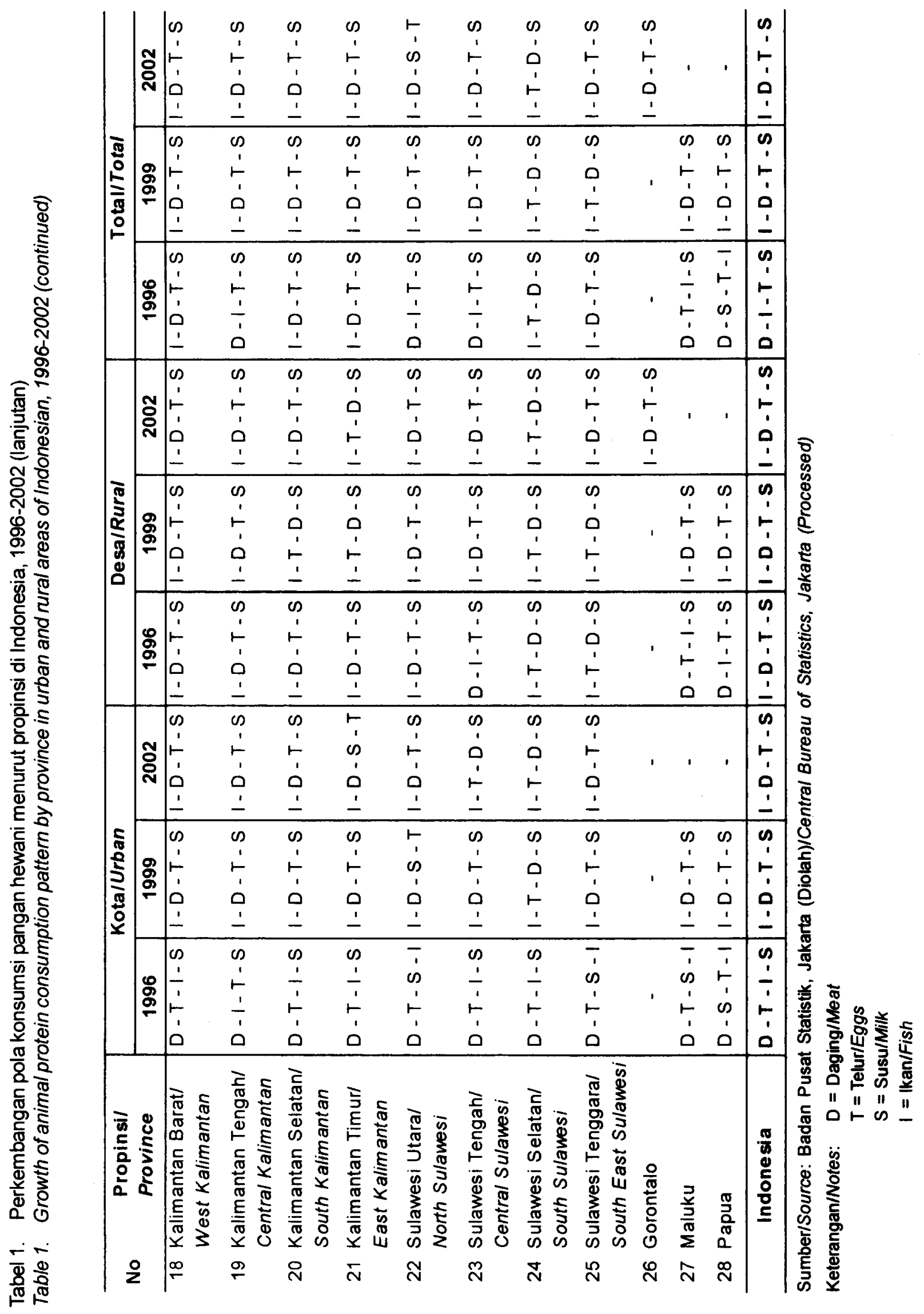


pola konsumsi pangan dibedakan atas pola konsumsi pangan pokok, pangan sumber protein, dan sebagainya. Dalam kajian ini dimaksudkan untuk mengetahui pola konsumsi pangan sumber protein terutama yang berasal dari pangan hewani, yaitu daging, telur, ikan dan susu. Perkembangan pola konsumsi pangan hewani di Indonesia dari tahun 1996 sampai tahun 2002 menurut wilayah yaitu daerah pedesaan dan perkotaan, yang disarikan pada Tabel 1.

Tabel 1. menunjukkan bahwa pola konsumsi pangan hewani di Indonesia pada tahun 1996 adalah daging-ikan-telur-susu. Terjadi perubahan pola konsumsi pangan hewani pada tahun 1999 dan 2002 yaitu ikan-daging-telur-susu. Hal ini menunjukkan bahwa di antara lauk hewani, secara relatif penduduk Indonesia lebih banyak makan ikan daripada daging dan telur, dengan kata lain ikan berperan banyak dalam menyumbang protein hewani, terutama pada saat krisis ekonomi (1999) dan masa pemulihan (2002).

Pada masa krisis, ikan dikonsumsi paling banyak masyarakat Indonesia, baru kemudian daging, telur dan susu. Kecuali pada beberapa propinsi yaitu NAD, Sumatera Utara, Sumatera Barat, Sumatera Selatan, Sulawesi Selatan, dan Sulawesi Tenggara, pola konsumsi pangan hewani yang terbentuk setelah ikan yang banyak dikonsumsi kemudian adalah telur, daging dan susu. Demikian pula halnya dengan pola konsumsi pada masa pemulihan, dimana ikan dikonsumsi paling banyak, kecuali di Daerah Istimewa Yogyakarta yang kembali pada pola konsumsi semula (daging-telur-ikan-susu). Di wilayah perkotaan dan pedesaan, pola konsumsi pangan hewani pada tahun 1996 adalah dagingikan-telur-susu. Di lain pihak, pola konsumsi pangan hewani pada tahun 1999 dan 2002 sama dengan pola konsumsi pangan hewani secara keseluruhan Indonesia. Berdasarkan informasi tersebut, dapat kita lihat bahwa ikan berperan sebagai penyumbang protein hewani pada masa krisis ekonomi dan masa pemulihan. Hal ini menunjukkan bahwa telah terjadi perubahan pola konsumsi pangan hewani. Daging, yang pada awalnya merupakan pangan hewani yang paling panyak dikonsumsi berubah menjadi ikan. Berarti telah terjadi pergeseran preferensi konsumen untuk pangan hewani yaitu kesadaran akan gizi ikan/seafood bagi kesehatan dan kecerdasan. Kondisi tersebut didukung oleh harga produk perikanan yang umumnya relatif lebih rendah daripada produk peternakan terutama daging.

Secara tidak langsung, kondisi ini sesuai dengan harapan rekomendasi Widyakarya Nasional Pangan dan Gizi VI tahun 1998 bahwa angka kecukupan protein hewani itu $60 \%$ dipenuhi dari protein ikan dan $40 \%$ dari protein ternak. Paling tidak informasi tersebut sudah menunjukkan perubahan yang berarti, meskipun sampai sejauh ini tingkat konsumsinya masih berada di bawah angka kecukupan.

Berdasarkan hal tersebut di atas, dapat dilihat bahwa pada tahun 1996 kelompok protein dari ternak mendominasi di daerah perkotaan. Selanjutnya pada tahun 1999 dan 2002 kelompok protein dari ikanlah yang dominan, sedangkan di daerah pedesaan yang terjadi memang konsumsi kelompok protein dari ikanlah yang dominan, bahkan cenderung meningkat. Dibanding pangan hewani lainnya, ikan paling banyak dikonsumsi oleh penduduk. Hal ini menurut Soeharto (1987) didorong oleh: (1) produksi ikan melimpah, (2) harga relatif rendah, (3) nilai gizi tinggi, dan (4) ikan sudah memasyarakat. Hal ini juga merupakan indikator bahwa daging, telur+susu masih merupakan komoditi pangan mewah bagi masyarakat pedesaan pada umumnya.

Selain pola konsumsi pangan hewani, bila ditelaah lebih lanjut terhadap pola konsumsi ikannya sendiri (Tabel 2) maka diketahui bahwa secara spasial pada tahun 1996 umumnya hampir memiliki pola yang sama. Sebagian besar masyarakat mengkonsumsi ikan olahan, tuna dan kembung. Di tahun 1999 dan 2002, sebagian besar masyarakat pedesaan mengkonsumsi ikan olahan dan tuna sedangkan pada masyarakat perkotaan lebih banyak mengkonsumsi ikan tuna dan kembung.

Dari sisi mutu gizinya, ikan segar lebih baik dibandingkan ikan olahan karenanya, harapan terhadapa ikan yang dikonsumsi lebih banyak adalah ikan segar. Perlu dilakukan perlakuan khusus dalam upaya peningkatan konsumsi ikan jika kecenderungan ikan olahan yang dikonsumsi lebih banyak dibandingkan ikan segar. Dalam hal ini perlu dicermati adanya korelasi positif antara jenis ikan yang dikonsumsi dengan pendapatan. Semakin tinggi tingkat pendapatan semakin besar peluang untuk mengkonsumsi produk pangan berprotein tinggi seperti ikan dan produk hasil laut lainnya.

Hal tersebut mengindikasikan bahwa masyarakat perkotaan yang memiliki pendapatan relatif lebih baik dibanding masyarakat pedesaan lebih banyak mengkonsumsi ikan yang memiliki mutu lebih baik. Lain halnya dengan masyarakat pedesaan, lebih menyukai mengkonsumsi ikan olahan yang memang harganya lebih murah dan mudah didapat. Hal ini menunjukkan bahwa konsumsi ikan banyak dipengaruhi oleh ikan yang tersedia dimana ketersediaan ini banyak ditentukan oleh produksinya. Namun demikian, walaupun produksinya sudah cukup, keadaan ini belum menjamin konsumsinya juga 
Tabel 2. Pola konsumsi ikan di Indonesia, 1996-2002

Table 2. Fish consumption pattern in Indonesia, 1996-2002

\begin{tabular}{lccc}
\hline & 1996 & 1999 & 2002 \\
\hline Kota/Urban & OL-TN-KB-SR & TN-KB-OL-SR & KB-TN-OL-SR \\
Desa/Rural & OL-TN-KB-TR & OL-TN-KB-GB & OL-TN-SR-GB \\
Kota+Desa/Urban+Rural & OL-TN-KB-KL & OL-TN-KB-SR & TN-OL-KB-MJ \\
\hline
\end{tabular}

Sumber/Source: Badan Pusat Statistik, Jakarta (Diolah)/Central Bureau of Statistics, Jakarta (Processed) Keterangan :

\begin{tabular}{|c|c|c|}
\hline TN: Tuna/Tunas & TR & Teri/Anchovies \\
\hline Selar/Trevallies & MJ & Mujair/Tilapias \\
\hline Ikan olahan/Processed fish & GB & Gabus/Snakehead fish \\
\hline Kembung/Mackere/s & $\mathrm{KL}$ & Ikan kaleng/Canned fish \\
\hline
\end{tabular}

cukup, karena adanya berbagai faktor yang berpengaruh. Oleh karenanya upaya peningkatan konsumsi ikan dengan menjamin pemerataan di semua wilayah sebaiknya ditempuh, didukung dengan teknologi pasca panen untuk peningkatan mutu konsumsi pangan.

\section{Perkembangan Konsumsi lkan dan Sumbangannya pada Tingkat Wilayah}

Perkembangan konsumsi pangan dari tahun 1996 sampai dengan 2002 dalam bentuk energi di berbagai propinsi (kota+desa) pada umumnya terjadi penurunan pada tahun 1999 dan kembali meningkat pada tahun 2002 meskipun belum pulih sebagaimana tahun 1996. Kecuali di beberapa wilayah, diantaranya adalah Jawa Timur, Bali dan Nusa Tenggara Barat yang peningkatan pada tahun 2002 melebihi tahun 1996 (Tabel 3).

Sejumlah propinsi yang ada pada tahun 1996 ratarata konsumsi energi penduduknya sudah di atas 2000 kkal, maka pada tahun 1999 kecuali NAD, Sumatera Barat, Bali, Kalteng dan Sulut mengalami peningkatan, sejumlah propinsi justru mengalami penurunan di bawah $2000 \mathrm{kkal}$. Hal ini diduga sebagai akibat terjadinya krisis ekonomi.

Demikian pula halnya dengan konsumsi protein, dalam periode tahun 1996 sampai 2002 pada umumnya terjadi kondisi yang sama, yaitu penurunan pada tahun 1999 dan peningkatan kembali pada tahun 2002 (Tabel 4). Pada tahun 1996 terdapat 3 propinsi yang konsumsi proteinnya masih di bawah $50 \mathrm{gram} /$ kap/hari yaitu Jawa Timur, Maluku dan Irian Jaya; sedangkan pada tahun 1999 kondisi yang terjadi justru sebaliknya dimana sebagian besar propinsi rata-rata konsumsi proteinnya di bawah 50 gram/ kap/hari. Namun demikian pada tahun 2002 keadaan sudah cukup membaik sehingga rata-rata konsumsi proteinnya meningkat di atas 50 gram/kap/ hari meskipun masih di bawah rata-rata angka kecukupan nasional yang dianjurkan.

Perkembangan peranan ikan dalam pola konsumsi pangan penduduk di berbagai propinsi dalam periode tahun 1996 sampai 2002 menunjukkan bahwa secara keseluruhan (kota+desa) sumbangan ikan terhadap konsumsi energi mengalami penurunan, kecuali Propinsi Sulawesi Utara yang mengalami peningkatan (Tabel 5). Di wilayah Jawa dan Bali yang merupakan wilayah padat penduduk pun ternyata sumbangan ikan terhadap total konsumsi energi berkisar $\leqslant 2 \%$. Sementara itu di wilayah Sumatra sumbangan ikan terhadap total konsumsi energi mendekati hampir 4\%, dan hanya Sulawesi Tenggara dan Maluku yang konsumsi ikannya mampu menyumbang $>4 \%$

Dalam hal protein, ikan memegang peranan penting dalam pola konsumsi pangan penduduk. Perkembangan ikan sebagai penyumbang konsumsi protein di semua propinsi menurut wilayah (desa+kota) disajikan pada Tabel 6. Dari data tabel ini terlihat bahwa konsumsi protein dari ikan yang tinggi ( $=10$ gram/kap/hari) tingkat konsumsinya adalah di wilayah Sulawesi, sebagian Kalimantan dan sebagian Sumatra. Di wilayah lainnya terutama Jawa, Bali dan Nusa Tenggara kondisinya masih cukup memprihatinkan, berkisar jauh di bawah $10 \mathrm{gram} / \mathrm{kap} /$ hari bahkan mencapai < $8 \mathrm{gram}$. kap/hari saja.

Konsumsi protein ikan yang masih rendah menunjukkan bahwa perilaku konsumsi ikan belum menjadi kebiasaan dalam pola konsumsi pangan hewani. Preferensi ikan konsumen dapat dijadikan 


\begin{tabular}{|c|c|c|c|c|c|c|c|c|c|c|c|c|c|c|c|c|c|}
\hline \multirow{3}{*}{ 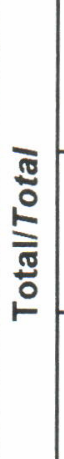 } & ণ్ & ' & $\begin{array}{l}\infty \\
0 \\
0 \\
0 \\
\text { N } \\
\text { i. }\end{array}$ & $\frac{\overline{o g}}{\grave{i}}$ & 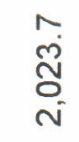 & $\begin{array}{l}m \\
\stackrel{m}{0} \\
\text { N } \\
\text { N }\end{array}$ & 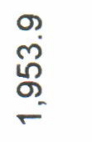 & $\begin{array}{l}\overline{\hat{O}} \\
\text { i }\end{array}$ & 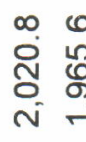 & 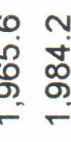 & 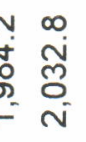 & $\begin{array}{l}\text { م } \\
\stackrel{\infty}{\infty} \\
\infty \\
-\end{array}$ & & & 趈 & $\begin{array}{l}n \\
\stackrel{0}{d} \\
\stackrel{+}{N} \\
\text { N }\end{array}$ & $\begin{array}{l}0 \\
\ddot{0} \\
\tilde{O} \\
\text { Ni }\end{array}$ \\
\hline & $\stackrel{\text { g }}{\stackrel{g}{\circ}}$ & $\begin{array}{l}\dot{v} \\
\dot{y} \\
\dot{v} \\
\sim\end{array}$ & Бே & $\begin{array}{l}\text { No } \\
\text { Ò } \\
\text { O } \\
\text { N }\end{array}$ & $\begin{array}{l}\text { م. } \\
\text { oे } \\
\stackrel{8}{-}\end{array}$ & $\begin{array}{l}\circ \\
\stackrel{\circ}{\sigma} \\
\stackrel{-}{\circ}\end{array}$ & $\begin{array}{l}\check{-} \\
\infty \\
\infty \\
-\end{array}$ & 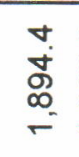 & 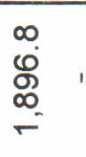 & $\begin{array}{l}N \\
1 \\
1 \\
\\
-\end{array}$ & 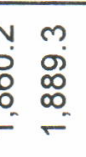 & $\begin{array}{l}\frac{m}{n} \\
\stackrel{n}{R}\end{array}$ & 总 & $\begin{array}{l}\text { Na } \\
\stackrel{N}{N} \\
-\end{array}$ & ' & 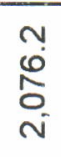 & $\begin{array}{l}0 \\
\stackrel{n}{n} \\
\infty \\
- \\
-\end{array}$ \\
\hline & $\begin{array}{l}\mathscr{8} \\
\stackrel{\sigma}{\digamma}\end{array}$ & $\frac{\infty}{\dot{m}}$ & $\begin{array}{l}\hat{N} \\
\stackrel{O}{C} \\
\bar{i}\end{array}$ & $\begin{array}{l}\stackrel{0}{\grave{n}} \\
\stackrel{N}{N}\end{array}$ & 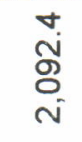 & $\frac{n}{\frac{n}{6}}$ & $\frac{\mathscr{0}}{\stackrel{N}{N}}$ & $\begin{array}{l}\infty \\
\stackrel{\infty}{\infty} \\
\stackrel{\infty}{\sim}\end{array}$ & 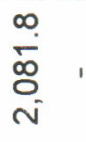 & 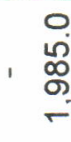 & 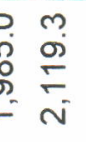 & $\begin{array}{l}\overline{\hat{\alpha}} \\
\infty \\
\infty \\
-\end{array}$ & 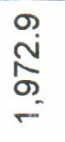 & $\begin{array}{l}\text { Oे } \\
\text { ட. } \\
\infty \\
--\end{array}$ & ' & i. & 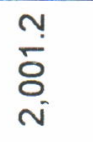 \\
\hline \multirow{3}{*}{$\overline{\mathbf{Q}}$} & ণั & ' & $\begin{array}{l}\hat{N} \\
\stackrel{0}{0} \\
\text { ì }\end{array}$ & $\frac{\stackrel{O}{+}}{\underset{\sim}{N}}$ & 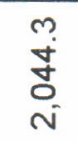 & $\frac{\stackrel{\circ}{m}}{\stackrel{m}{i}}$ & 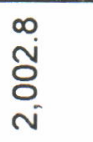 & $\begin{array}{l}\text { O } \\
\text { ల్ } \\
\text { i } \\
\text { N }\end{array}$ & 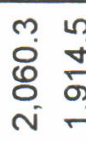 & ' & 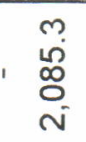 & $\begin{array}{l}m \\
\text { ڤే } \\
\text { o } \\
-\end{array}$ & 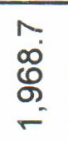 & 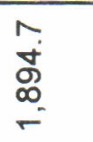 & $\begin{array}{l}\text { त्र } \\
\text { గ్ } \\
\text { N }\end{array}$ & 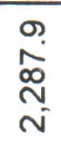 & $\begin{array}{l}\text { Na } \\
0 \\
\text { O } \\
\text { N }\end{array}$ \\
\hline & $\stackrel{\mathscr{g}}{\stackrel{\circ}{\leftarrow}}$ & 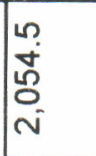 & $\begin{array}{l}\mathbf{v} \\
\stackrel{N}{N} \\
\text { N }\end{array}$ & $\begin{array}{l}0 \\
\infty \\
0 \\
0 \\
N\end{array}$ & $\begin{array}{l}\stackrel{\nabla}{0} \\
\mathscr{8} \\
\stackrel{-}{-}\end{array}$ & 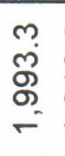 & $\begin{array}{l}\stackrel{6}{\infty} \\
\stackrel{\sigma}{\sigma} \\
-\end{array}$ & 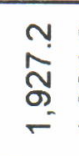 & $\begin{array}{l}\stackrel{N}{~} \\
\text { סे } \\
-\end{array}$ & ' & ' & $\begin{array}{l}0 \\
\infty \\
\stackrel{0}{R} \\
\stackrel{0}{-}\end{array}$ & $\begin{array}{l}0 \\
\infty \\
\infty \\
0 \\
-\end{array}$ & $\begin{array}{l}\underset{N}{N} \\
\stackrel{N}{-}\end{array}$ & ' & $\begin{array}{l}\stackrel{\varphi}{\oplus} \\
\stackrel{\sigma}{i}\end{array}$ & $\begin{array}{l}n \\
\infty \\
\infty \\
\infty \\
- \\
-\end{array}$ \\
\hline & $\begin{array}{l}\stackrel{\circ}{\circ} \\
\stackrel{\circ}{-}\end{array}$ & 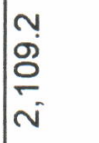 & $\begin{array}{l}\text { Na } \\
\infty \\
o \\
\text { i } \\
\text { N }\end{array}$ & $\begin{array}{l}\infty \\
\stackrel{\infty}{0} \\
\text { N } \\
\text { }\end{array}$ & $\begin{array}{l}\infty \\
\text { लె. } \\
\text { Oे } \\
\text { Ni }\end{array}$ & $\begin{array}{l}\stackrel{\sim}{N} \\
\stackrel{\sim}{N} \\
\sim\end{array}$ & 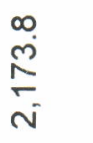 & $\begin{array}{l}\frac{\sigma}{-} \\
\frac{0}{i} \\
\end{array}$ & $\begin{array}{l}\stackrel{d}{n} \\
\frac{n}{2} \\
\stackrel{i}{n}\end{array}$ & ' & $\begin{array}{l}\infty \\
0 \\
0 \\
\\
\text { in }\end{array}$ & $\begin{array}{l}\infty \\
\stackrel{\infty}{ } \\
\infty \\
\infty \\
-\end{array}$ & $\begin{array}{l}\circ \\
\infty \\
\vdots \\
\text { i }\end{array}$ & $\begin{array}{l}n \\
\stackrel{0}{0} \\
\infty \\
-\end{array}$ & ' & $\underset{\stackrel{i}{\sim}}{\stackrel{i}{N}}$ & 莒 \\
\hline \multirow{3}{*}{ 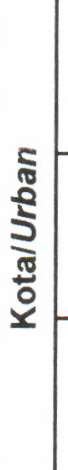 } & ণ్రి & ' & 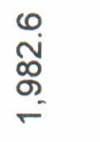 & $\begin{array}{l}0 \\
\dot{U} \\
\text { Oे } \\
\text { i }\end{array}$ & $\begin{array}{l}\check{g} \\
\stackrel{-}{\circ} \\
\stackrel{-}{-}\end{array}$ & 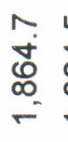 & $\begin{array}{l}n \\
\tilde{U} \\
0 \\
\infty \\
-\end{array}$ & $\begin{array}{l}m \\
\frac{5}{\infty} \\
-\end{array}$ & 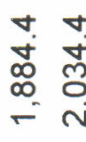 & 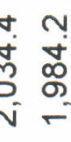 & 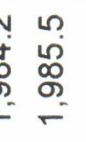 & $\begin{array}{l}\infty \\
\infty \\
\infty \\
\infty \\
\infty \\
-\end{array}$ & $\begin{array}{l}\text { Na } \\
0 \\
\infty \\
\infty \\
=\end{array}$ & $\begin{array}{l}\infty \\
\infty \\
\infty \\
\infty \\
-\end{array}$ & 足 & $\begin{array}{l}n \\
\stackrel{0}{N} \\
\stackrel{N}{N}\end{array}$ & $\begin{array}{l}0 \\
\dot{J} \\
\stackrel{\sigma}{N}\end{array}$ \\
\hline & $\stackrel{\mathscr{g}}{\stackrel{\circ}{-}}$ & $\hat{~}$ & $\begin{array}{l}\text { @ } \\
\underset{\sim}{\sim} \\
\stackrel{\infty}{-}\end{array}$ & $\begin{array}{l}\text { m. } \\
\text { oे } \\
\text { o } \\
-\end{array}$ & $\begin{array}{l}m \\
\stackrel{m}{\circ} \\
\infty \\
-\end{array}$ & \begin{tabular}{l}
$\infty$ \\
\multirow{L}{N}{} \\
$\stackrel{N}{2}$ \\
-
\end{tabular} & \begin{tabular}{l}
$\hat{\infty}$ \\
\multirow{\infty}{\infty}{} \\
$\infty$ \\
-
\end{tabular} & $\begin{array}{l}\stackrel{N}{+} \\
\stackrel{\infty}{\infty} \\
-\end{array}$ & 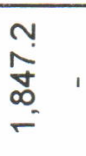 & 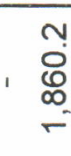 & 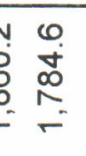 & 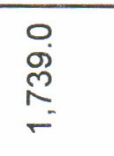 & 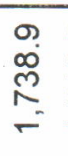 & $\begin{array}{l}\stackrel{n}{0} \\
\underline{n} \\
r \\
r\end{array}$ & 1 & 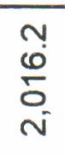 & مُ \\
\hline & $\stackrel{\mathscr{L}}{\circ}$ & 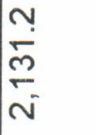 & 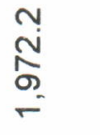 & $\begin{array}{l}\overline{\text { ĩ }} \\
\text { O } \\
\text { N }\end{array}$ & $\begin{array}{l}\text { o } \\
\stackrel{9}{0} \\
0 \\
0 \\
\text { i }\end{array}$ & $\begin{array}{l}n \\
\infty \\
\infty \\
- \\
-\end{array}$ & $\begin{array}{l}\text { م } \\
\infty \\
0 \\
0 \\
\text { N }\end{array}$ & $\begin{array}{l}\infty \\
\stackrel{\infty}{\Omega} \\
\stackrel{-}{\sigma} \\
-\end{array}$ & 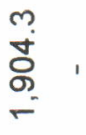 & $\begin{array}{l}0 \\
\text { I. } \\
\text { ' } \\
\stackrel{2}{-}\end{array}$ & 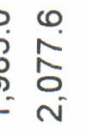 & $\begin{array}{l}0 \\
\stackrel{0}{0} \\
\infty \\
-\end{array}$ & 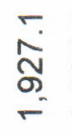 & $\begin{array}{l}\text { O } \\
\stackrel{\infty}{1} \\
\infty \\
-\end{array}$ & I & 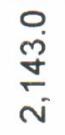 & $\begin{array}{l}\stackrel{\infty}{-} \\
\stackrel{-}{\infty} \\
\stackrel{\alpha}{\alpha} \\
-\end{array}$ \\
\hline \multicolumn{2}{|c|}{ 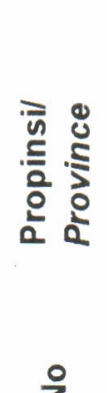 } & 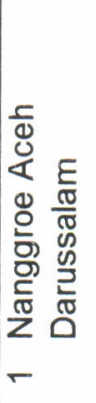 & 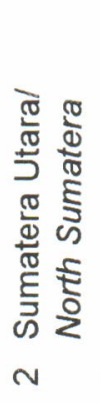 & 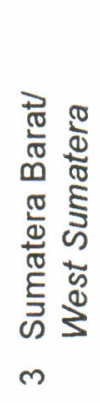 & $\begin{array}{l}\vec{\sigma} \\
\frac{\pi}{\alpha} \\
+\end{array}$ & & 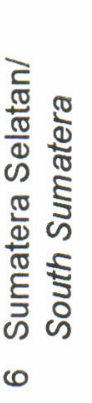 & 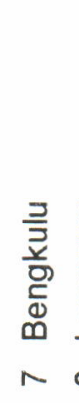 & 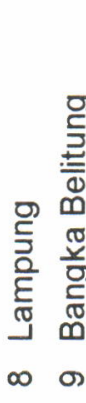 & 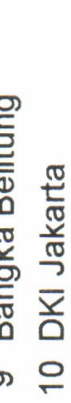 & 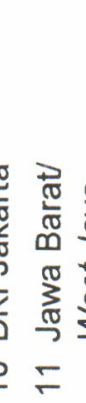 & 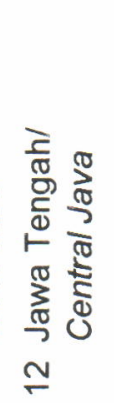 & 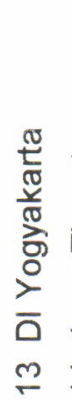 & 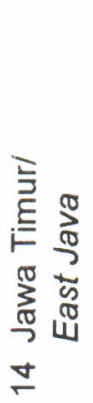 & 岳 & $\begin{array}{l}\overline{\overline{\widetilde{D}}} \\
\underline{\omega}\end{array}$ & 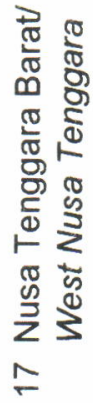 \\
\hline
\end{tabular}




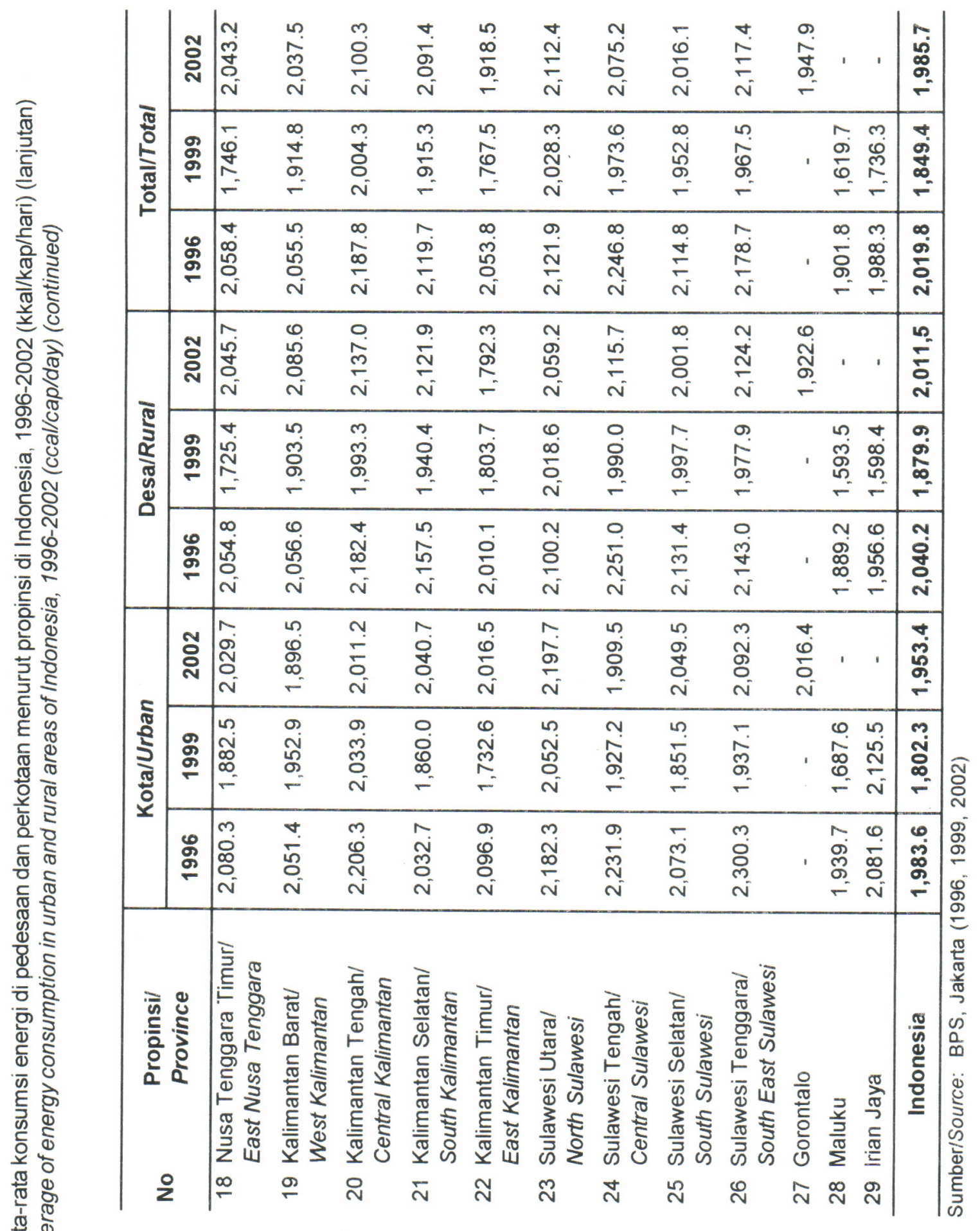

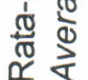

लं

瀂兑 


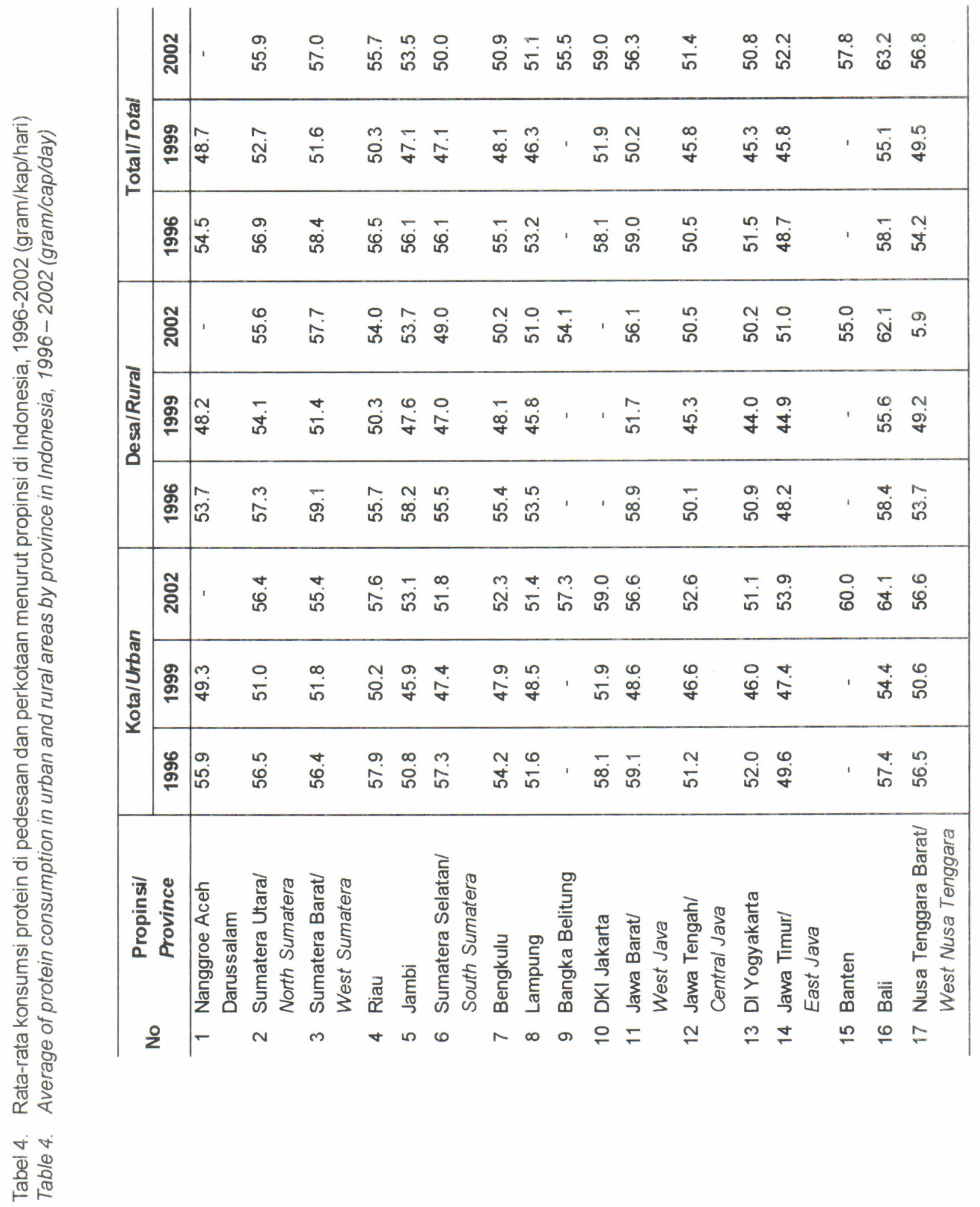




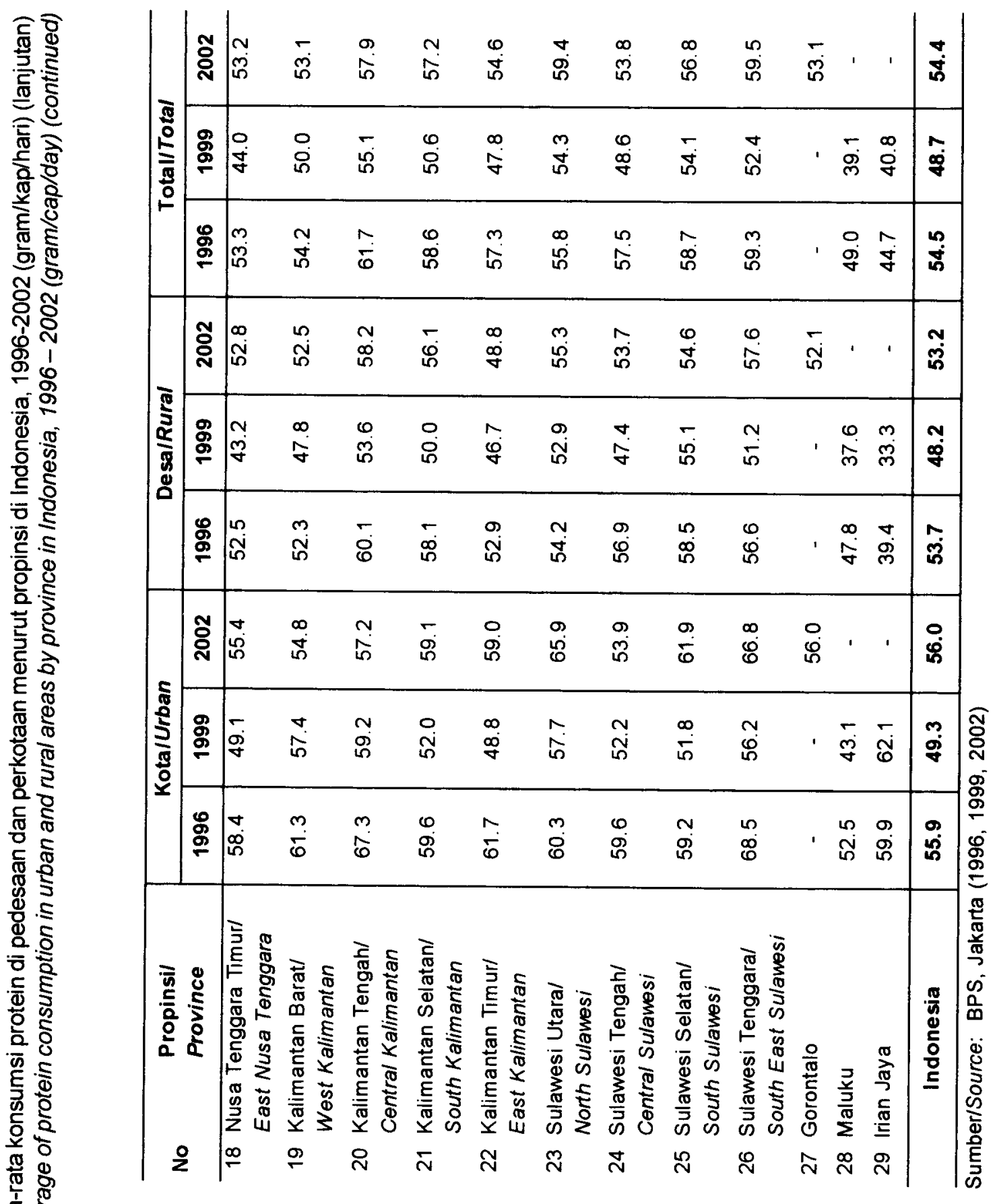




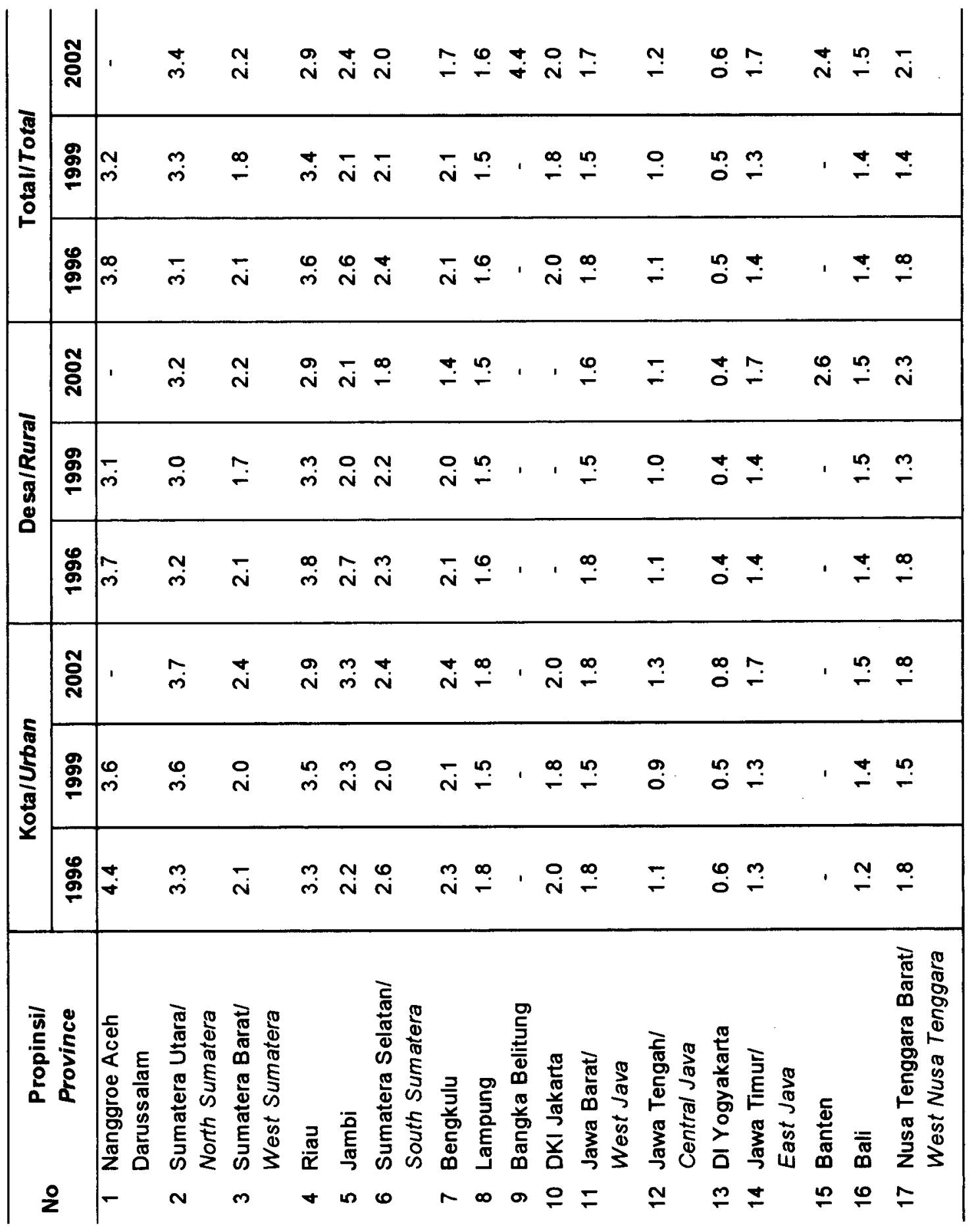




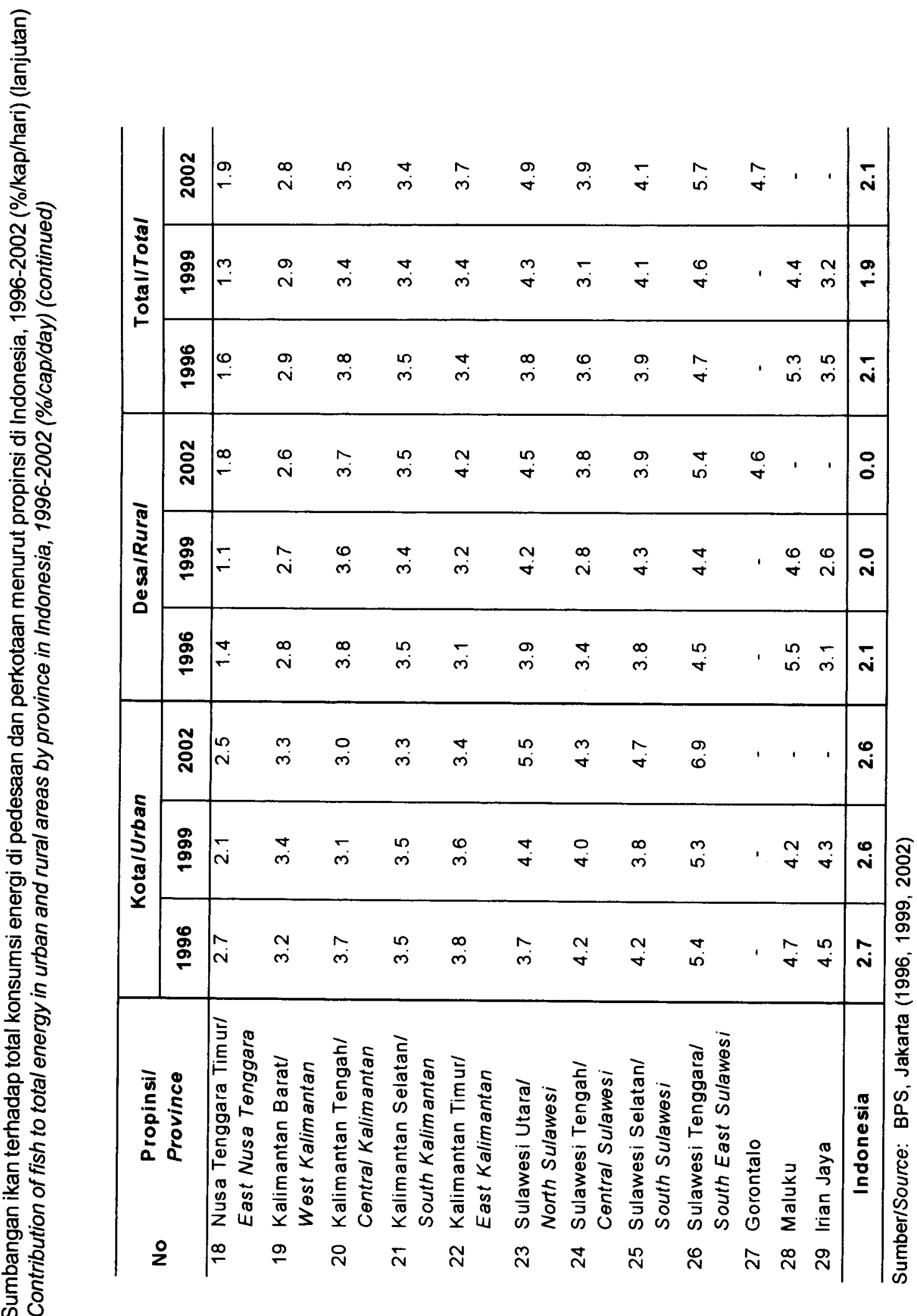

in 要 


\begin{tabular}{|c|c|c|c|c|c|c|c|c|c|c|c|c|c|c|c|c|c|c|}
\hline \multirow{3}{*}{ 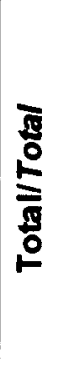 } & 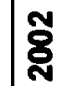 & ' & $\stackrel{m}{\stackrel{N}{N}}$ & $\underset{\infty}{\mathbf{\infty}}$ & $\overline{0}$ & $\underset{\infty}{+}$ & $\stackrel{+}{6}$ & $\stackrel{\infty}{\infty}$ & in & $\stackrel{\underset{N}{ \pm}}{\underset{\sim}{*}}$ & & $\bar{\sigma}$ & $\underset{m}{\infty}$ & $\stackrel{\infty}{\leftarrow}$ & $\ddot{m}$ & $\underset{\infty}{\infty}$ & $\begin{array}{l}\infty \\
\infty\end{array}$ & $\stackrel{N}{N}$ \\
\hline & $\begin{array}{l}\stackrel{g}{\circ} \\
\stackrel{5}{\sigma}\end{array}$ & $\overline{0}$ & $\Xi$ & $\bar{\sigma}$ & $\stackrel{\circ}{=}$ & $\hat{\sigma}$ & $\stackrel{+}{6}$ & $\underset{\oplus}{m}$ & 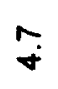 & 1 & $\begin{array}{l}\infty \\
i \\
\text { in }\end{array}$ & $\stackrel{9}{+}$ & $\hat{i}$ & $\stackrel{N}{-}$ & $\stackrel{\infty}{m}$ & 1 & ஸั & $\stackrel{\forall}{+}$ \\
\hline & \% & $\stackrel{\sim}{N}$ & $\stackrel{\varphi}{=}$ & $\bar{\infty}$ & $\stackrel{\leftrightarrow}{\stackrel{0}{N}}$ & $\stackrel{\varphi}{\sigma}$ & $\underset{\infty}{\infty}$ & $\stackrel{n}{r}$ & $\hat{~ i n}$ & 1 & $\stackrel{N}{\sim}$ & $\underset{6}{\mathscr{\sigma}}$ & $\stackrel{m}{m}$ & $\stackrel{0}{-}$ & $\stackrel{Y}{\forall}$ & . & $\overline{i n}$ & $\stackrel{0}{0}$ \\
\hline \multirow{3}{*}{ 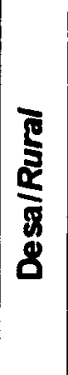 } & §్ & , & $\stackrel{\sigma}{=}$ & $\underset{\infty}{\forall}$ & $\stackrel{m}{\circ}$ & $\stackrel{\varphi}{r}$ & مُ & $\stackrel{9}{+}$ & is & $\stackrel{+}{ \pm}$ & ' & مُ & $\stackrel{\sim}{m}$ & $\stackrel{+}{\square}$ & m & $\underset{\infty}{\infty}$ & $\begin{array}{l}\infty \\
i \\
i\end{array}$ & $\stackrel{\sigma}{\sim}$ \\
\hline & $\stackrel{\$}{\$}$ & סִ & $\stackrel{\infty}{\stackrel{0}{0}}$ & $\stackrel{0}{0}$ & 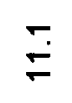 & $\ddot{\varphi}$ & $\stackrel{\bullet}{6}$ & $\dddot{m}_{0}^{\circ}$ & $\stackrel{r}{+}$ & ' & ' & $\bar{\omega}$ & $\stackrel{\infty}{\sim}$ & 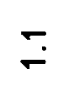 & $\stackrel{\infty}{\infty}$ & ' & in & $\underset{+}{+}$ \\
\hline & $\stackrel{\$}{\$}$ & $\stackrel{N}{r}$ & $\stackrel{\infty}{=}$ & $\underset{\infty}{+}$ & $\stackrel{\circ}{\ddot{m}}$ & $\stackrel{m}{\circ}$ & $\underset{\infty}{0}$ & $\stackrel{+}{\sim}$ & $\underset{\dot{\infty}}{\dot{\varphi}}$ & ' & & $\hat{0}$ & $\stackrel{m}{m}$ & $\stackrel{m}{-}$ & $\stackrel{m}{+}$ & ' & it & $\underset{0}{\circ}$ \\
\hline \multirow{3}{*}{$\frac{5}{\frac{5}{5}}$} & శ్ క్ & ' & $\stackrel{\leftrightarrow}{\stackrel{\sim}{\sim}}$ & $\underset{\infty}{\infty}$ & $\stackrel{\infty}{\sigma}$ & $\stackrel{m}{\circ}$ & $\stackrel{+}{\sim}$ & $\stackrel{\infty}{\sim}$ & $\bar{\omega}$ & $\stackrel{\infty}{\stackrel{\infty}{m}}$ & $\stackrel{\circ}{\sim}$ & $\ddot{\theta}$ & $\stackrel{\infty}{m}$ & $\bar{i}$ & in & $\underset{\infty}{m}$ & $\underset{\infty}{\infty}$ & $\underset{0}{\circ}$ \\
\hline & 朵 & | & $\stackrel{n}{=}$ & $\underset{\boldsymbol{\theta}}{\tilde{O}}$ & $\stackrel{9}{\circ}$ & $\underset{0}{0}$ & م) & $\ddot{m}_{0}^{m}$ & $\stackrel{\infty}{+}$ & , & $\begin{array}{l}\infty \\
\text { in }\end{array}$ & $\stackrel{\varphi}{\forall}$ & $\stackrel{\leftrightarrow}{N}$ & $\stackrel{m}{\longrightarrow}$ & $\stackrel{\infty}{\infty}$ & ' & $\stackrel{\infty}{+}$ & $\stackrel{f}{+}$ \\
\hline & $\begin{array}{l}\mathscr{8} \\
\stackrel{5}{\sigma}\end{array}$ & ִִ & $\stackrel{+}{\rightleftarrows}$ & $\stackrel{N}{N}$ & $\stackrel{\varphi}{=}$ & $\stackrel{\varphi}{\sim}$ & $\underset{\infty}{\infty}$ & $\stackrel{\infty}{N}$ & $=$ & 1 & $\stackrel{N}{\sim}$ & $\underset{\bullet}{\mathscr{0}}$ & $\stackrel{m}{m}$ & $\stackrel{\infty}{\rightarrow}$ & $\stackrel{0}{+}$ & ' & $\stackrel{\infty}{+}$ & $\underset{0}{0}$ \\
\hline \multirow{2}{*}{\multicolumn{2}{|c|}{ 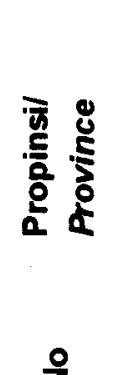 }} & 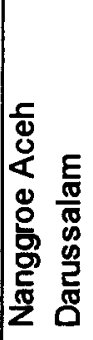 & 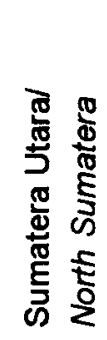 & 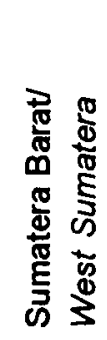 & : & : & 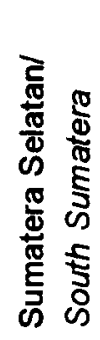 & 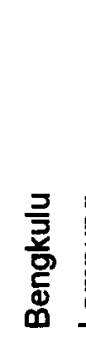 & $\begin{array}{l}\text { 뫃 } \\
\text { 흘 } \\
\text { 밈 }\end{array}$ & 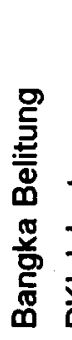 & 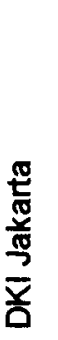 & 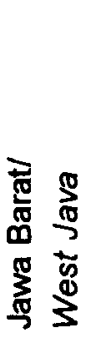 & 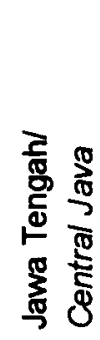 & 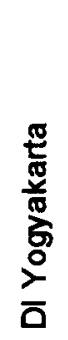 & 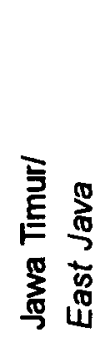 & 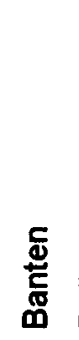 & $\overline{\overline{0}}$ & 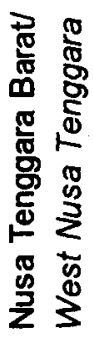 \\
\hline & 일 & - & $N$ & $m$ & $\theta$ & n & $\omega$ & $\wedge$ & $\infty$ & os & 으 & $=$ & $\stackrel{\sim}{\sim}$ & $\stackrel{m}{\sim}$ & 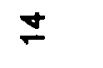 & $\stackrel{n}{2}$ & 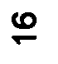 & $\approx$ \\
\hline
\end{tabular}




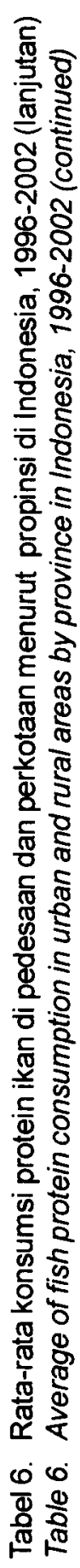

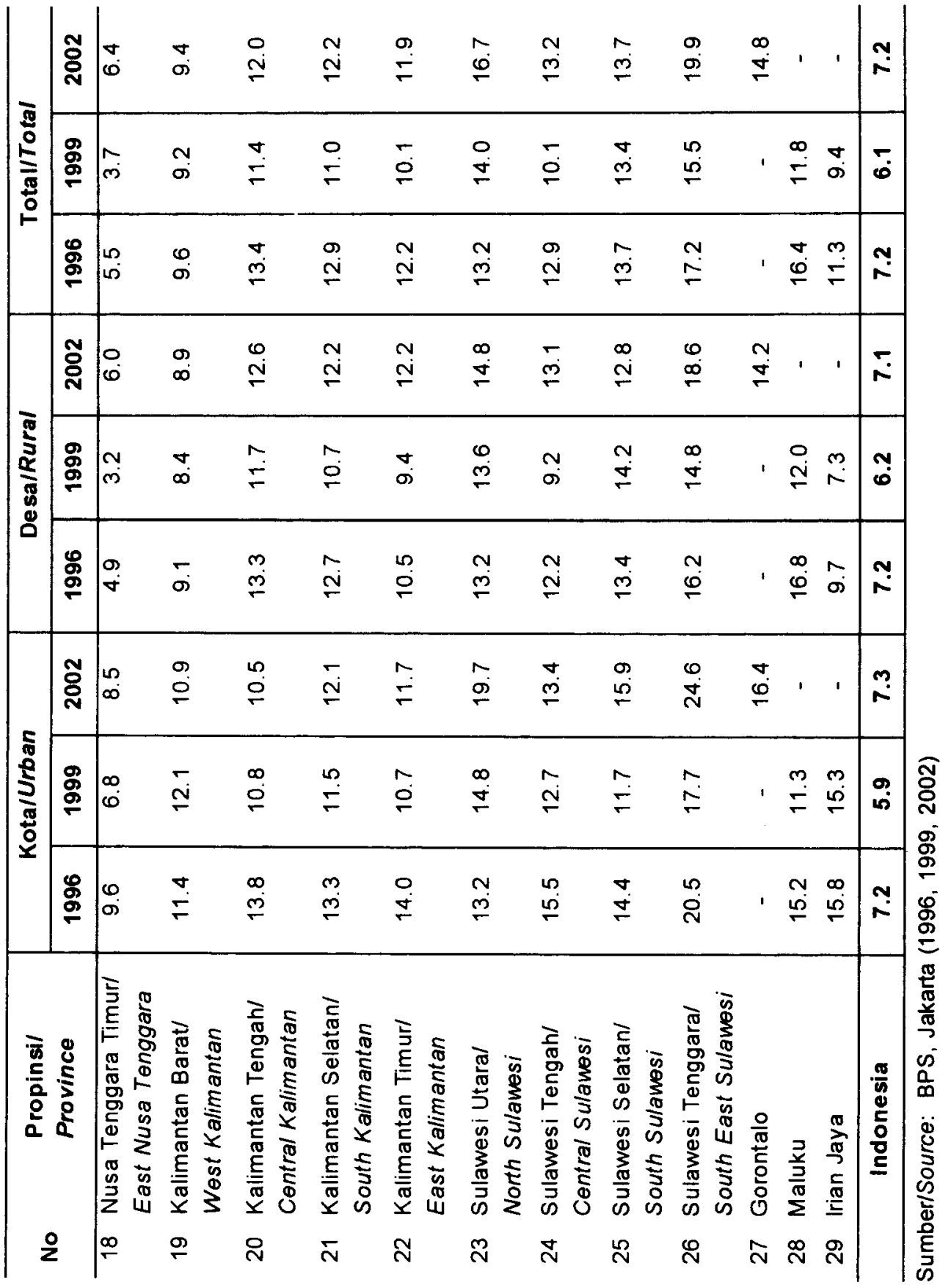


acuan bagi produsen ikan untuk membuat inovasi baru dalam pengolahan ikan sehingga dapat meningkatkan pemasaran, misalnya membuat produk olahan dari ikan. Selain itu, diharapkan produsen ikan dapat meningkatkan citra produk ikannya dengan menjelaskan kelebihan-kelebihan produk tersebut.

Instansi terkait, khususnya Departemen Kelautan dan Perikanan sebaiknya meningkatkan promosi "Gemar Makan Ikan" serta memperhatikan produksi, distribusi, dan penyediaan fasilitas. Hal ini sangatlah penting terutama dalam memberi kesadaran pada masyarakat dengan cara memberikan penyuluhan dari pengenalan kandungan gizi sampai tahap pengolahan ikan, lomba memasak ikan ataupun kegiatan lain yang dapat menjadi motivasi masyarakat untuk mengkonsumsi ikan. Jika kegiatan tersebut sudah ada, maka perlu ditingkatkan lagi sehingga masyarakat semakin memahami pentingnya mengkonsumsi ikan. Selain itu perlu dilakukan penentuan prioritas sasaran perbaikan konsumsi pangan dan gizi khususnya untuk ikan di berbagai wilayah ini terutama dikaitkan dengan golongan pendapatannya.

\section{Implikasi Kebijakan}

Krisis ekonomi berdampak sangat besar terhadap perubahan perilaku konsumsi pangan hewani. Dimana telah terjadi pergeseran preferensi konsumen dari produk peternakan terhadap produk perikanan. Pada masa ini, ikan dikonsumsi sebagian besar masyarakat Indonesia, baru kemudian daging, telur dan susu. Pola konsumsi ikannya sendiri cukup bervariasi baik di wilayah pedesaan maupun perkotaan.

Keragaan ini merupakan tantangan bagi pelaku kebijakan terutama bagian perencanaan pangan dan gizi di sektor kelautan dan perikanan untuk menjamin produk perikanan baik ikan segar ataupun ikan olahan yang dikonsumsi oleh masyarakat itu aman bagi kesehatan. Konsumsi ikan segar selain ikan tuna masih dapat ditingkatkan lagi. Kebijakan perikanan yang berorientasi boleh ekspor karenanya tidak melupakan kebutuhan konsumsi dalam negeri, kurang pasokan ikan di dalam negeri sendiri dapat berdampak tidak hanya sekedar kurang terpenuhinya konsumsi protein hewani tetapi dalam jangka panjang akan berdampak pada penurunan kualitas sumberdaya manusia.

Pengambil kebijakan juga dapat melakukan prioritasi terhadap jenis-jenis ikan yang harus ditingkatkan dari segi konsumsi dan ketersediaannya baik itu ikan laut maupun ikan tawar. Upaya tersebut juga akan lebih baik jika disertai dengan sistem distribusi dan pemasaran yang baik, sehingga dapat menjangkau masyarakat baik secara fisik maupun ekonomis. Hal ini tentunya perlu didukung oleh teknologi pasca panen yang tepat sehingga hasil produksi tidak banyak terbuang dalam proses penanganan. Dalam upaya peningkatan pangan sumber protein hewani, ikan selayaknya dijadikan tumpuan karena selain harganya yang relatif murah juga ikan telah diidentiikasi memiliki keunggulan sebagaimana yang telah diungkapkan sebelumnya. Melalui pemasaran sosial tentang pentingnya mengkonsumsi ikan.

\section{KESIMPULAN DAN SARAN}

Hasil analisis terhadap perkembangan pola konsumsi pangan hewani menurut wilayah menunjukkan bahwa pola konsumsi pangan hewani di Indonesia pada tahun 1996 adalah Daging-IkanTelur-Susu. Terjadi perubahan pola konsumsi pangan hewani pada tahun 1999 dan 2002 yaitu Ikan-DagingTelur-Susu. Hal ini menunjukkan bahwa ikan sangat berperan dalam menyumbang protein hewani, terutama pada saat krisis ekonomi (tahun 1999) dan masa pemulihan (tahun 2002).

Gerakan Makan Ikan yang sudah dicanangkan oleh Departemen Kelautan dan Perikanan perlu disosialisikan di segenap lapisan masyarakat dan insidentil agar sasaran tercapai, sampai pada akhirnya makan ikan menjadi membudaya. Tentunya harus diiringi dengan terjaminnya ikan yang dikonsumsi itu aman dan memenuhi syarat kesehatan. Sehingga perlu dilakukan pengawasan di setiap lini, dalam hal ini yaitu produksi (penangkapan), pasca panen (pengolahan), distribusi (pemasaran) dan konsumsi.

\section{DAFTAR PUSTAKA}

Almatsier, S. 2002. Prinsip Dasar Ilmu Gizi. PT. Gramedia, Jakarta.

Badan Pusat Statistik. 1996. Survei Sosial Ekonomi Nasional 1996. BPS, Jakarta.

Badan Pusat Statistik. 1996. Konsumsi Kalori dan Protein Penduduk Indonesia dan Propinsi 1996. BPS, Jakarta.

Badan Pusat Statistik. 1999. Survei Sosial Ekonomi Nasional 1999. BPS, Jakarta.

Badan Pusat Statistik. 1999. Konsumsi Kalori dan Protein Penduduk Indonesia dan Propinsi 1999. BPS, Jakarta.

Badan Pusat Statistik. 2002. Survei Sosial Ekonomi Nasional 2002. BPS, Jakarta.

Badan Pusat Statistik. 2002. Konsumsi Kalori dan Protein Penduduk Indonesia dan Propinsi 2002. BPS, Jakarta.

Dahuri, R. 2003. Paradigma Baru Pembangunan Indonesia Berbasis Kelautan. Orasi Ilmiah Guru Besar Tetap Bidang Pengelolaan Sumberdaya Pesisir dan Lautan, Fakultas Perikanan dan IImu Kelautan - IPB. Bogor. 
Departemen Kelautan dan Perikanan. 2004. Refleksi Pembangunan Kelautan dan Perikanan Tahun 2004 dan Rencana Kegiatan Tahun 2005. Departemen Kelautan dan Perikanan Republik Indonesia. Jakarta.

Harli M. 2004. Makan ikan mencegah kanker. hhttp:// uww. depkes.go.id. index. php? option = articles \& task $=$ viewarticle \& articl $=37 \&$ itemid $=3 . \mathrm{htm} /$

Lubis B. 1987. Pengolahan dan pemasaran ikan untuk pemerataan konsumsi. Di dalam: Seminar Manfaat Ikan bagi Pembangunan Sumberdaya Manusia; Jakarta, 31 Agustus - 1 September.
Soeharto, S.T. 1987. Faktor-Faktor Pendorong dan Kendala dalam Konsumsi Ikan. Seminar Manfaat Ikan bagi Pembangunan Sumberdaya Manusia. 31 Agustus - 1 September 1987. Departemen Kesehatan, KLH, Jakarta.

Wahyuni, M. 1994. Potensi Gizi Ikan dan Hasil Laut untuk Kecerdasan Bangsa. Materi kuliah Pengantar Teknologi Hasil Perikanan. Fakultas Perikanan. IPB, Bogor. 


\section{LAMPIRAN}

Lampiran 1. Perkembangan konsumsi pangan hewani menurut propinsi di kota dan desa, 1996-2002 Appendix 1. Growth of animal protein consumption by province in urban and rural areas, 1996-2002

\begin{tabular}{|c|c|c|c|c|c|c|c|c|c|c|c|c|c|}
\hline \multirow{3}{*}{ No } & \multirow{3}{*}{$\begin{array}{l}\text { Propinsi/ } \\
\text { Province }\end{array}$} & \multicolumn{12}{|c|}{ Tahun/Year } \\
\hline & & \multicolumn{4}{|c|}{1996} & \multicolumn{4}{|c|}{1999} & \multicolumn{4}{|c|}{2002} \\
\hline & & D & $\mathbf{T}$ & $\mathrm{s}$ & I & D & $T$ & $\mathbf{s}$ & 1 & D & $T$ & $s$ & I \\
\hline 1 & $\begin{array}{l}\text { Nanggroe Aceh } \\
\text { Darussalam }\end{array}$ & 4.6 & 6.4 & 0.9 & 8.1 & 2.4 & 5.6 & 1.1 & 42.6 & - & - & - & - \\
\hline 2 & $\begin{array}{l}\text { Sumatera Utara/ } \\
\text { North Sumatera }\end{array}$ & 9.3 & 6.7 & 2.6 & 18.7 & 3.9 & 4.4 & 1.5 & 43.6 & 6.8 & 5.9 & 2.6 & 48.4 \\
\hline 3 & $\begin{array}{l}\text { Sumatera Barat/ } \\
\text { West Sumatera }\end{array}$ & 9.3 & 7.5 & 2.3 & 12.2 & 5.4 & 5.8 & 1.9 & 24.0 & 9.0 & 8.4 & 3.3 & 32.4 \\
\hline 4 & Riau & 11.5 & 8.3 & 3.5 & 13.7 & 7.3 & 6.8 & 2.5 & 45.5 & 14.1 & 10.1 & 3.9 & 39.1 \\
\hline 5 & Jambi & 7.3 & 6.8 & 2.2 & 15.2 & 5.3 & 4.8 & 1.6 & 26.7 & 7.3 & 7.0 & 1.7 & 33.2 \\
\hline 6 & $\begin{array}{l}\text { Sumatera Selatan/ } \\
\text { South Sumatera }\end{array}$ & 9.0 & 7.7 & 2.8 & 10.2 & 4.3 & 5.3 & 1.8 & 24.8 & 6.5 & 7.2 & 1.9 & 24.9 \\
\hline 7 & Bengkulu & 11.0 & 6.7 & 2.3 & 7.9 & 5.6 & 4.3 & 1.8 & 24.1 & 6.5 & 4.9 & 1.5 & 22.6 \\
\hline 8 & Lampung & 7.8 & 7.0 & 1.5 & 7.9 & 5.2 & 4.5 & 1.4 & 17.8 & 5.0 & 5.3 & 1.4 & 21.4 \\
\hline 9 & Bangka Belitung & - & - & - & - & - & - & - & - & 7.4 & 7.4 & 2.8 & 55.5 \\
\hline 10 & DKI Jakarta & 23.4 & 9.9 & 5.4 & 4.4 & 11.0 & 7.1 & 4.9 & 21.4 & 18.8 & 9.8 & 6.9 & 26.2 \\
\hline 11 & $\begin{array}{l}\text { Jawa Barat/ } \\
\text { West Java }\end{array}$ & 11.9 & 7.0 & 2.1 & 12.2 & 5.1 & 4.4 & 1.2 & 19.0 & 9.7 & 7.3 & 2.6 & 23.4 \\
\hline 12 & $\begin{array}{l}\text { Jawa Tengah/ } \\
\text { Central Java }\end{array}$ & 7.6 & 5.4 & 1.5 & 6.6 & 4.1 & 3.3 & 1.2 & 10.2 & 6.7 & 5.6 & 1.9 & 13.2 \\
\hline 13 & DI Yogyakarta & 10.8 & 7.4 & 2.2 & 2.7 & 4.9 & 4.2 & 2.0 & 4.0 & 9.5 & 6.6 & 3.2 & 5.7 \\
\hline 14 & $\begin{array}{l}\text { Jawa Timur/ } \\
\text { East Java }\end{array}$ & 6.9 & 4.9 & 1.3 & 7.5 & 4.2 & 3.1 & 1.1 & 14.1 & 6.7 & 5.8 & 2.1 & 20.3 \\
\hline 15 & Bali & 12.8 & 6.4 & 2.0 & 10.9 & 8.8 & 5.0 & 1.6 & 19.5 & 16.9 & 7.8 & 3.5 & 22.2 \\
\hline 16 & $\begin{array}{l}\text { Nusa Tenggara Barat/ } \\
\text { West Nusa Tenggara }\end{array}$ & 7.4 & 4.4 & 1.0 & 7.4 & 4.8 & 2.6 & 0.7 & 17.3 & 7.2 & 4.5 & 0.7 & 27.4 \\
\hline 17 & $\begin{array}{l}\text { Nusa Tenggara Timur/ } \\
\text { East Nusa Tenggara }\end{array}$ & 10.6 & 2.2 & 1.4 & 6.7 & 6.2 & 1.3 & 0.7 & 17.4 & 8.1 & 1.7 & 1.0 & 24.8 \\
\hline 18 & $\begin{array}{l}\text { Kalimantan Barat/ } \\
\text { West Kalimantan }\end{array}$ & 12.3 & 6.0 & 2.1 & 13.3 & 7.4 & 4.5 & 1.7 & 36.4 & 10.4 & 6.5 & 2.3 & 36.5 \\
\hline 19 & $\begin{array}{l}\text { Kalimantan Tengah/ } \\
\text { Central Kalimantan }\end{array}$ & 15.5 & 7.3 & 2.9 & 13.4 & 7.6 & 5.7 & 2.5 & 42.7 & 11.6 & 7.2 & 2.5 & 46.9 \\
\hline 20 & $\begin{array}{l}\text { Kalimantan Selatan/ } \\
\text { South Kalimantan }\end{array}$ & 8.7 & 7.4 & 2.6 & 9.0 & 4.4 & 4.2 & 1.5 & 43.1 & 8.9 & 6.6 & 2.5 & 47.3 \\
\hline 21 & $\begin{array}{l}\text { Kalimantan Timur/ } \\
\text { East Kalimantan }\end{array}$ & 11.3 & 7.7 & 4.3 & 8.0 & 6.1 & 6.1 & 3.0 & 38.7 & 10.8 & 8.4 & 4.6 & 46.7 \\
\hline 22 & $\begin{array}{l}\text { Sulawesi Utara/ } \\
\text { North Sulawesi }\end{array}$ & 9.7 & 3.7 & 2.7 & 6.6 & 4.7 & 2.3 & 2.0 & 54.7 & 7.4 & 4.0 & 4.2 & 64.4 \\
\hline
\end{tabular}


Lampiran 1. Perkembangan konsumsi pangan hewani menurut propinsi di kota dan desa, 1996-2002 (lanjutan) Appendix 1. Growth of animal protein consumption by province in urban and rural areas, 1996-2002 (continued)

\begin{tabular}{|c|c|c|c|c|c|c|c|c|c|c|c|c|c|}
\hline \multirow{3}{*}{ No } & \multirow{3}{*}{$\begin{array}{l}\text { Propinsil } \\
\text { Province }\end{array}$} & \multicolumn{12}{|c|}{ Tahun/Year } \\
\hline & & \multicolumn{4}{|c|}{1996} & \multicolumn{4}{|c|}{1999} & \multicolumn{4}{|c|}{2002} \\
\hline & & D & $T$ & $\mathbf{s}$ & 1 & D & $T$ & $\mathbf{s}$ & $\mathbf{I}$ & D & $\mathbf{T}$ & $\mathbf{s}$ & $\mathbf{I}$ \\
\hline 23 & $\begin{array}{l}\text { Sulawesi Tengah/ } \\
\text { Central Sulawesi }\end{array}$ & 8.0 & 4.8 & 2.6 & 6.6 & 4.3 & 2.9 & 2.0 & 41.4 & 4.6 & 3.6 & 2.2 & 50.5 \\
\hline 24 & $\begin{array}{l}\text { Sulawesi Selatan/ } \\
\text { South Sulawesi }\end{array}$ & 4.8 & 5.2 & 2.1 & 8.6 & 2.9 & 3.7 & 1.8 & 51.7 & 3.7 & 5.4 & 2.1 & 53.3 \\
\hline 25 & $\begin{array}{l}\text { Sulawesi Tenggara/ } \\
\text { South East Sulawesi }\end{array}$ & 4.9 & 3.9 & 2.5 & 5.2 & 2.1 & 2.5 & 1.4 & 61.8 & 2.7 & 2.6 & 1.5 & 76.8 \\
\hline 26 & Gorontalo & - & - & - & - & - & - & - & - & 4.8 & 2.1 & 1.2 & 58.1 \\
\hline 27 & Maluku & 3.7 & 2.4 & 2.0 & 2.0 & 2.4 & 1.9 & 1.3 & 46.4 & - & - & - & - \\
\hline 28 & Papua & 13.3 & 3.5 & 4.0 & 2.3 & 7.6 & 4.8 & 3.3 & 45.8 & - & - & - & - \\
\hline & Indonesia & 9.6 & 6.1 & 2.2 & 9.0 & 5.2 & 4.1 & 1.7 & 25.4 & 8.9 & 6.4 & 2.7 & 29.3 \\
\hline
\end{tabular}

Sumber/Source: Badan Pusat Statistik, Jakarta (Diolah)/Central Bureau of Statistics, Jakarta (Processed)

Keterangan/Notes:

$\mathrm{D}=$ Daging/Meat

$\mathrm{T}=$ Telur/Eggs

$\mathrm{S}=$ Susu/Milk

$\mathrm{I}=$ Ikan /Fish 
Lampiran 2. Perkembangan konsumsi pangan hewani menurut propinsi di kota, 1996-2002 Appendix 2. Growth of animal protein consumption by province in urban areas, 1996-2002

\begin{tabular}{|c|c|c|c|c|c|c|c|c|c|c|c|c|c|}
\hline \multirow{3}{*}{ No } & \multirow{3}{*}{$\begin{array}{l}\text { Propinsi/ } \\
\text { Province }\end{array}$} & \multicolumn{12}{|c|}{ Tahun/Year } \\
\hline & & \multicolumn{4}{|c|}{1996} & \multicolumn{4}{|c|}{1999} & \multicolumn{4}{|c|}{2002} \\
\hline & & $\mathbf{D}$ & $\mathbf{T}$ & $\mathbf{s}$ & 1 & D & $\mathbf{T}$ & $\mathbf{s}$ & 1 & D & $T$ & $\mathbf{s}$ & 1 \\
\hline 1 & $\begin{array}{l}\text { Nanggroe Aceh } \\
\text { Darussalam }\end{array}$ & 7.1 & 9.1 & 2.1 & 4.6 & 3.0 & 6.7 & 1.8 & 43.6 & - & - & - & - \\
\hline 2 & $\begin{array}{l}\text { Sumatera Utara/ } \\
\text { North Sumatera }\end{array}$ & 12.9 & 8.6 & 4.4 & 10.6 & 5.1 & 5.5 & 2.7 & 43.9 & 9.1 & 7.6 & 4.3 & 49.3 \\
\hline 3 & $\begin{array}{l}\text { Sumatera Barat/ } \\
\text { West Sumatera }\end{array}$ & 14.3 & 8.7 & 4.1 & 6.7 & 7.0 & 7.2 & 3.5 & 23.1 & 12.8 & 10.5 & 5.5 & 31.4 \\
\hline 4 & Riau & 15.6 & 9.4 & 5.6 & 10.4 & 9.2 & 8.0 & 3.9 & 41.6 & 19.8 & 11.0 & 5.7 & 37.9 \\
\hline 5 & Jambi & 11.1 & 7.9 & 3.5 & 9.5 & 7.8 & 6.1 & 2.5 & 26.8 & 13.1 & 8.5 & 3.5 & 38.4 \\
\hline 6 & $\begin{array}{l}\text { Sumatera Selatan/ } \\
\text { South Sumatera }\end{array}$ & 14.0 & 10.3 & 5.4 & 7.6 & 7.4 & 6.4 & 3.5 & 22.3 & 12.1 & 10.1 & 4.3 & 28.1 \\
\hline 7 & Bengkulu & 14.4 & 8.5 & 3.4 & 7.2 & 8.7 & 5.7 & 3.0 & 23.4 & 11.5 & 6.6 & 2.7 & 29.6 \\
\hline 8 & Lampung & 9.8 & 8.9 & 2.5 & 4.9 & 7.9 & 6.9 & 2.8 & 18.3 & 9.7 & 8.0 & 3.3 & 23.7 \\
\hline 9 & Bangka Belitung & - & - & - & - & - & - & - & - & 10.2 & 8.8 & 4.4 & 53.1 \\
\hline 10 & DKI Jakarta & 23.4 & 9.9 & 5.4 & 4.4 & 11.0 & 7.1 & 4.9 & 21.4 & 18.8 & 9.8 & 6.9 & 26.2 \\
\hline 11 & $\begin{array}{l}\text { Jawa Barat/ } \\
\text { West Java }\end{array}$ & 17.6 & 8.7 & 4.0 & 9.6 & 8.3 & 5.7 & 2.4 & 17.5 & 13.4 & 8.7 & 4.2 & 24.2 \\
\hline 12 & $\begin{array}{l}\text { Jawa Tengah/ } \\
\text { Central Java }\end{array}$ & 11.1 & 6.8 & 2.9 & 4.8 & 5.8 & 4.1 & 2.1 & 9.8 & 9.7 & 6.8 & 3.1 & 14.4 \\
\hline 13 & DI Yogyakarta & 14.9 & 8.8 & 3.7 & 2.2 & 5.8 & 4.9 & 3.0 & 4.0 & 11.1 & 7.4 & 4.8 & 6.4 \\
\hline 14 & $\begin{array}{l}\text { Jawa Timur/ } \\
\text { East Java }\end{array}$ & 11.5 & 6.4 & 2.7 & 4.8 & 6.1 & 4.0 & 2.1 & 13.9 & 10.2 & 7.1 & 3.6 & 20.2 \\
\hline 15 & Bali & 14.5 & 7.0 & 3.4 & 7.7 & 10.7 & 6.1 & 2.7 & 17.6 & 19.8 & 8.4 & 5.3 & 21.6 \\
\hline 16 & $\begin{array}{l}\text { Nusa Tenggara Barat/ } \\
\text { West Nusa Tenggara }\end{array}$ & 11.6 & 6.0 & 2.2 & 7.3 & 7.7 & 4.0 & 1.1 & 18.0 & 9.1 & 5.4 & 1.3 & 22.9 \\
\hline 17 & $\begin{array}{l}\text { Nusa Tenggara Timur/ } \\
\text { East Nusa Tenggara }\end{array}$ & 14.1 & 5.5 & 3.4 & 4.0 & 7.3 & 3.0 & 1.9 & 27.6 & 10.9 & 6.5 & 3.9 & 33.7 \\
\hline 18 & $\begin{array}{l}\text { Kalimantan Barat/ } \\
\text { West Kalimantan }\end{array}$ & 20.4 & 10.9 & 5.4 & 9.0 & 14.5 & 7.3 & 4.4 & 45.2 & 16.3 & 9.0 & 5.4 & 41.6 \\
\hline 19 & $\begin{array}{l}\text { Kalimantan Tengah/ } \\
\text { Central Kalimantan }\end{array}$ & 20.8 & 10.3 & 4.7 & 11.6 & 11.8 & 7.7 & 4.5 & 39.9 & 14.8 & 8.0 & 4.4 & 39.2 \\
\hline 20 & $\begin{array}{l}\text { Kalimantan Selatan/ } \\
\text { South Kalimantan }\end{array}$ & 11.5 & 9.5 & 4.6 & 6.5 & 6.6 & 5.5 & 2.5 & 44.0 & 13.5 & 9.1 & 4.4 & 45.8 \\
\hline 21 & $\begin{array}{l}\text { Kalimantan Timur/ } \\
\text { East Kalimantan }\end{array}$ & 15.7 & 9.7 & 5.5 & 6.9 & 8.1 & 7.4 & 4.4 & 40.1 & 14.4 & 9.8 & 6.2 & 44.3 \\
\hline 22 & $\begin{array}{l}\text { Sulawesi Utaral } \\
\text { North Sulawesi }\end{array}$ & 13.5 & 5.9 & 4.9 & 4.8 & 6.4 & 2.9 & 3.4 & 56.8 & 9.8 & 5.3 & 6.1 & 73.6 \\
\hline
\end{tabular}


Lampiran 2. Perkembangan konsumsi pangan hewani menurut propinsi di kota, 1996-2002 (lanjutan) Appendix 2. Growth of animal protein consumption by province in urban areas, 1996-2002 (continued)

\begin{tabular}{|c|c|c|c|c|c|c|c|c|c|c|c|c|c|}
\hline \multirow{3}{*}{ No } & \multirow{3}{*}{$\begin{array}{l}\text { Propinsi/ } \\
\text { Province }\end{array}$} & \multicolumn{12}{|c|}{ Tahun/Year } \\
\hline & & \multicolumn{4}{|c|}{1996} & \multicolumn{4}{|c|}{1999} & \multicolumn{4}{|c|}{2002} \\
\hline & & D & $T$ & $\mathbf{s}$ & 1 & D & $\mathbf{T}$ & $\mathbf{s}$ & 1 & $\mathbf{D}$ & $T$ & s & 1 \\
\hline 23 & $\begin{array}{l}\text { Sulawesi Tengah/ } \\
\text { Central Sulawesi }\end{array}$ & 8.2 & 6.7 & 4.0 & 5.9 & 5.3 & 4.2 & 3.2 & 48.1 & 4.9 & 5.7 & 4.3 & 50.2 \\
\hline 24 & $\begin{array}{l}\text { Sulawesi Selatan/ } \\
\text { South Sulawesi }\end{array}$ & 6.1 & 6.5 & 2.9 & 6.0 & 3.5 & 4.3 & 2.4 & 46.0 & 6.4 & 7.8 & 4.1 & 59.2 \\
\hline 25 & $\begin{array}{l}\text { Sulawesi Tenggara/ } \\
\text { South East Sulawesi }\end{array}$ & 8.1 & 5.8 & 4.5 & 4.0 & 3.8 & 3.6 & 2.4 & 68.6 & 5.6 & 5.4 & 2.8 & 94.2 \\
\hline 26 & Gorontalo & - & - & - & - & - & - & - & - & 6.9 & 3.5 & 2.6 & 64.8 \\
\hline 27 & Maluku & 5.0 & 3.7 & 3.4 & 3.1 & 2.7 & 2.5 & 2.0 & 45.0 & - & - & - & - \\
\hline 28 & Papua & 13.2 & 6.3 & 7.4 & 2.5 & 9.8 & 7.4 & 5.3 & 58.2 & - & - & - & - \\
\hline & Indonesia & 14.0 & 8.0 & 3.9 & 6.4 & 7.5 & 5.4 & 2.9 & 25.9 & 13.1 & 8.2 & 4.6 & 28.5 \\
\hline
\end{tabular}

Sumber/Source: Badan Pusat Statistik, Jakarta (Diolah)/Central Bureau of Statistics, Jakarta (Processed)

Keterangan/Notes:

$D=$ Daging/Meat

$\mathrm{T}=$ Telur $/ E g g s$

$S=$ Susu/Milk

$I=I$ Ikan/Fish 
Lampiran 3. Perkembangan konsumsi pangan hewani menurut propinsi di desa, 1996-2002 Appendix3. Growth of food consumption by province in rural areas, 1996-2002

\begin{tabular}{|c|c|c|c|c|c|c|c|c|c|c|c|c|c|}
\hline \multirow{3}{*}{ No } & \multirow{3}{*}{$\begin{array}{l}\text { Propinsi/ } \\
\text { Province }\end{array}$} & \multicolumn{12}{|c|}{ Tahun/Year } \\
\hline & & \multicolumn{4}{|c|}{1996} & \multicolumn{4}{|c|}{1999} & \multicolumn{4}{|c|}{2002} \\
\hline & & D & $T$ & $\mathbf{s}$ & 1 & D & $\mathbf{T}$ & $\mathbf{s}$ & 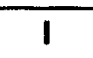 & D & $T$ & $\mathbf{s}$ & $I$ \\
\hline 1 & $\begin{array}{l}\text { Nanggroe Aceh } \\
\text { Darussalam }\end{array}$ & 3.8 & 5.5 & 0.5 & 9.3 & 1.8 & 4.5 & 0.5 & 41.5 & - & - & - & - \\
\hline 2 & $\begin{array}{l}\text { Sumatera Utara/ } \\
\text { North Sumatera }\end{array}$ & 6.6 & 5.3 & 1.2 & 24.6 & 3.0 & 3.6 & 0.6 & 43.4 & 5.2 & 4.7 & 1.4 & 47.7 \\
\hline 3 & $\begin{array}{l}\text { Sumatera Barat/ } \\
\text { West Sumatera }\end{array}$ & 7.3 & 7.1 & 1.7 & 14.3 & 4.7 & 5.2 & 1.3 & 24.3 & 7.5 & 7.5 & 2.4 & 32.8 \\
\hline 4 & Riau & 8.1 & 7.5 & 1.7 & 16.5 & 5.7 & 5.7 & 1.2 & 48.9 & 7.9 & 9.1 & 1.9 & 40.3 \\
\hline 5 & Jambi & 4.2 & 5.9 & 1.1 & 19.8 & 3.4 & 3.7 & 0.9 & 26.6 & 4.7 & 6.3 & 0.9 & 30.9 \\
\hline 6 & $\begin{array}{l}\text { Sumatera Selatan/ } \\
\text { South Sumatera }\end{array}$ & 6.2 & 6.3 & 1.4 & 11.6 & 2.6 & 4.6 & 0.9 & 26.2 & 3.8 & 5.8 & 0.7 & 23.3 \\
\hline 7 & Bengkulu & 7.7 & 5.0 & 1.2 & 8.5 & 2.5 & 3.0 & 0.7 & 24.8 & 4.2 & 4.2 & 1.0 & 19.5 \\
\hline 8 & Lampung & 6.8 & 5.9 & 1.0 & 9.5 & 3.6 & 3.2 & 0.7 & 17.5 & 3.7 & 4.6 & 0.9 & 20.7 \\
\hline 9 & Bangka Belitung & - & - & - & - & - & - & - & - & 5.1 & 6.3 & 1.5 & 57.4 \\
\hline 10 & DKI Jakarta & - & - & - & - & - & - & - & - & - & - & - & - \\
\hline 11 & $\begin{array}{l}\text { Jawa Barat/ } \\
\text { West Java }\end{array}$ & 8.7 & 6.0 & 1.1 & 13.6 & 3.2 & 3.6 & 0.5 & 19.9 & 5.8 & 5.8 & 0.8 & 22.6 \\
\hline 12 & $\begin{array}{l}\text { Jawa Tengah/ } \\
\text { Central Java }\end{array}$ & 5.7 & 4.6 & 0.7 & 7.6 & 3.0 & 2.8 & 0.7 & 10.5 & 4.7 & 4.7 & 1.0 & 12.3 \\
\hline 13 & DI Yogyakarta & 8.4 & 6.5 & 1.3 & 2.9 & 4.3 & 3.7 & 1.1 & 4.0 & 7.7 & 5.8 & 1.4 & 5.0 \\
\hline 14 & $\begin{array}{l}\text { Jawa Timurl } \\
\text { East Java }\end{array}$ & 4.5 & 4.1 & 0.6 & 8.9 & 3.1 & 2.6 & 0.5 & 14.2 & 4.1 & 4.8 & 1.1 & 20.4 \\
\hline 15 & Bali & 11.7 & 6.1 & 1.1 & 12.8 & 7.5 & 4.3 & 0.9 & 20.8 & 13.6 & 7.2 & 1.5 & 22.8 \\
\hline 16 & $\begin{array}{l}\text { Nusa Tenggara Barat/ } \\
\text { West Nusa Tenggara }\end{array}$ & 5.1 & 3.5 & 0.3 & 7.5 & 3.3 & 1.9 & 0.4 & 16.9 & 6.0 & 4.0 & 0.3 & 30.2 \\
\hline 17 & $\begin{array}{l}\text { Nusa Tenggara Timurl } \\
\text { East Nusa Tenggara }\end{array}$ & 9.2 & 0.9 & 0.7 & 7.8 & 5.8 & 0.6 & 0.2 & 13.1 & 7.5 & 0.7 & 0.5 & 23.0 \\
\hline 18 & $\begin{array}{l}\text { Kalimantan Barat/ } \\
\text { West Kalimantan }\end{array}$ & 9.6 & 4.3 & 1.0 & 14.7 & 4.8 & 3.4 & 0.6 & 33.1 & 8.3 & 5.7 & 1.2 & 34.8 \\
\hline 19 & $\begin{array}{l}\text { Kalimantan Tengah/ } \\
\text { Central Kalimantan }\end{array}$ & 11.5 & 5.0 & 1.5 & 14.8 & 4.3 & 4.2 & 1.0 & 44.8 & 10.1 & 6.8 & 1.6 & 50.3 \\
\hline 20 & $\begin{array}{l}\text { Kalimantan Selatan/ } \\
\text { South Kalimantan }\end{array}$ & 6.5 & 5.9 & 1.0 & 10.9 & 2.7 & 3.1 & 0.7 & 42.3 & 6.2 & 5.1 & 1.4 & 48.3 \\
\hline 21 & $\begin{array}{l}\text { Kalimantan Timur/ } \\
\text { East Kalimantan }\end{array}$ & 7.8 & 6.2 & 3.3 & 9.0 & 4.5 & 5.0 & 1.8 & 37.6 & 5.8 & 6.3 & 2.3 & 50.0 \\
\hline 22 & $\begin{array}{l}\text { Sulawesi Utaral } \\
\text { North Sulawesi }\end{array}$ & 7.5 & 2.4 & 1.5 & 7.5 & 3.7 & 2.0 & 1.3 & 53.6 & 5.8 & 3.2 & 2.9 & 58.6 \\
\hline
\end{tabular}


Lampiran 3. Perkembangan kunsumsi pangan hewani menurut propinsi di desa, 1996-2002 (lanjutan) Appendix3. Growth of food consumption by province in rural areas, 1996-2002 (continued)

\begin{tabular}{|c|c|c|c|c|c|c|c|c|c|c|c|c|c|}
\hline \multirow{3}{*}{ No } & \multirow{3}{*}{$\begin{array}{l}\text { Propinsil } \\
\text { Province }\end{array}$} & \multicolumn{12}{|c|}{ Tahun/Year } \\
\hline & & \multicolumn{4}{|c|}{1996} & \multicolumn{4}{|c|}{1999} & \multicolumn{4}{|c|}{2002} \\
\hline & & D & $T$ & s & 1 & D & $T$ & s & 1 & $\mathbf{D}$ & $T$ & $\mathbf{S}$ & I \\
\hline 23 & $\begin{array}{l}\text { Sulawesi Tengah/ } \\
\text { Central Sulawesi }\end{array}$ & 7.8 & 3.2 & 1.5 & 7.1 & 3.6 & 1.8 & 1.1 & 36.0 & 4.5 & 3.1 & 1.7 & 50.6 \\
\hline 24 & $\begin{array}{l}\text { Sulawesi Selatan/ } \\
\text { South Sulawesi }\end{array}$ & 3.8 & 4.2 & 1.4 & 10.5 & 2.5 & 3.3 & 1.4 & 55.8 & 2.5 & 4.3 & 1.2 & 50.7 \\
\hline 25 & $\begin{array}{l}\text { Sulawesi Tenggaral } \\
\text { South East Sulawesi }\end{array}$ & 2.4 & 2.4 & 1.1 & 6.2 & 0.8 & 1.6 & 0.6 & 56.2 & 1.8 & 1.8 & 1.2 & 72.0 \\
\hline 26 & Gorontalo & - & - & - & - & - & - & - & - & 4.0 & 1.6 & 0.6 & 55.4 \\
\hline 27 & Maluku & 2.6 & 1.3 & 0.9 & 1.2 & 2.1 & 1.4 & 0.7 & 47.4 & - & - & - & - \\
\hline & Papua & 13.5 & 1.0 & 0.9 & 2.1 & 4.6 & 1.1 & 0.6 & 28.7 & - & - & - & - \\
\hline & Indonesia & 6.7 & 4.9 & 1.0 & 10.7 & 3.5 & 3.2 & 0.7 & 25.1 & 5.5 & 4.9 & 1.2 & 30.0 \\
\hline
\end{tabular}

Sumber/Source: Badan Pusat Statistik, Jakarta (Diolah)/Central Bureau of Statistics, Jakarta (Processed)

Keterangan/Notes:

$\mathrm{D}=$ Daging/Meat

$T=$ Telur $/ E g g s$

$S=$ Susu/Milk

$\mathrm{I}=\mathrm{Ikan} /$ Fish 